\title{
Eosinophils: Old Players in a New Game
}

\author{
Sastre B ${ }^{1,2}$, Rodrigo-Muñoz JM',2, Garcia-Sanchez DA', Cañas JA ${ }^{1,2}$, del Pozo $V^{1,2}$ \\ 'Department of Immunology, IIS-Fundación Jiménez Díaz, Madrid, Spain \\ ${ }^{2}$ CIBER de Enfermedades Respiratorias (CIBERES), Madrid, Spain
}

J Investig Allergol Clin Immunol 2018; Vol. 28(5): 289-304

doi: 10.18176/jiaci.0295

\begin{abstract}
Eosinophils are terminal polymorphonuclear cells with a high number of cytoplasmic granules that originate in bone marrow. Some are exosomes, which contain multiple molecules, such as specific eosinophilic proteins, cytokines, chemokines, enzymes, and lipid mediators that contribute to the effector role of these cells. Moreover, exosomes present a large number of receptors that allow them to interact with multiple cell types. Eosinophils play an important role in defense against infestations and are a key element in asthma and allergic diseases. Eosinophils are recruited to the inflamed area in response to stimuli, modulating the immune response through the release to the extracellular medium of their granule-derived content. Various mechanisms of degranulation have been identified. Polymorphonuclear leukocytes contain multivesicular bodies that generate exosomes that are secreted into the extracellular environment. Eosinophilic exosomes participate in multiple processes and mechanisms. Eosinophils participate actively in asthma and are hallmarks of the disease. The cells migrate to the inflammatory focus and contribute to epithelial damage and airway remodeling. Given their relevance in this pathology, new therapeutic tools have been developed that target mainly eosinophils and their receptors.

In this manuscript, we provide a global, updated vision of the biology of eosinophils and the role of eosinophils in respiratory diseases, particularly asthma. We also summarize asthma treatments linked to eosinophils and new therapeutic strategies based on biological products in which eosinophils and their receptors are the main targets.
\end{abstract}

Key words: Eosinophils. Exosomes. Asthma. Biological treatments.

\section{Resumen}

Los eosinófilos son células polimorfonucleares terminales originadas en la médula ósea con un número importante de gránulos citoplasmáticos, algunos de los cuales son exosomas, que contienen múltiples moléculas como proteínas eosinofílicas específicas, citocinas, quimiocinas, enzimas y mediadores lipídicos que contribuyen al papel efector de estas células. Además, presentan una gran cantidad de receptores que les permiten interactuar con múltiples tipos celulares. Los eosinófilos desempeñan un papel importante en la defensa contra las infestaciones y son un elemento clave en el asma y las enfermedades alérgicas. Los eosinófilos se reclutan hacia el área de inflamación en respuesta a varios estímulos, modulando la respuesta inmune a través de la liberación al medio extracelular del contenido derivado de sus gránulos, existiendo diferentes mecanismos de degranulación. Estos leucocitos polimorfonucleares contienen cuerpos multivesiculares que generan exosomas que se secretan al ambiente extracelular. Estos exosomas eosinofílicos participan en múltiples procesos y mecanismos. En relación con la enfermedad asmática, los eosinófilos participan activamente en los elementos distintivos de esta patología. Estas células migran al foco inflamatorio y contribuyen al daño del epitelio y a la remodelación de las vías respiratorias. Debido a su relevancia en esta patología, se han desarrollado nuevas herramientas terapéuticas, siendo los eosinófilos y sus receptores sus objetivos principales.

En este manuscrito, proporcionamos una visión global y actualizada sobre la biología de los eosinófilos, su papel en las enfermedades respiratorias, centrando nuestra atención en la patología asmática, así como un resumen de los tratamientos y nuevas estrategias terapéuticas basadas en tratamientos biológicos en los que los eosinófilos y sus receptores son los principales objetivos.

Palabras clave: Eosinófilos. Exosomas. Asma. Tratamientos biológicos. 


\section{Introduction}

Eosinophils were first described by Paul Ehrlich in 1879 . Since their presence in pathogenic processes was identified in 1922 [1], many studies have attempted to understand their unique biology. Based on this growing body of knowledge, eosinophils have ceased to be understood as passive cells and are now known as powerful effector cells. Eosinophils are involved in host defense, immune and adaptive responses, tissue damage, and airway remodelling [2].

\section{Eosinophil Differentiation}

In humans, eosinophil progenitors are $\mathrm{CD} 34^{+}$hematopoietic stem cells (common myeloid progenitor) [3]. Under normal conditions, eosinophils are produced from $\mathrm{CD} 34^{+}$progenitor cells located in the bone marrow under the effect of granulocyte macrophage-colony stimulating factor (GM-CSF), interleukin (IL) 3, and IL-5 [4]. IL-5 is an essential cytokine in eosinophil development, as it promotes terminal differentiation, growth, and survival, as well as the activation of eosinophils [5]. The role of IL-5 in eosinophil differentiation has been widely described, and several studies have shown that IL-5-deficient mice do not develop peripheral blood or tissue eosinophilia under asthmatic conditions or in helminth infection [6,7]. Several authors recently demonstrated the eosinophilopoietic potential of IL-33 and thymic stromal lymphopoietin (TSLP) $[8,9]$. Since these CD $34^{+}$cells can coexpress IL-5 receptor alpha subunit (IL-5R $\alpha$ ) on their surface [10], CD34 ${ }^{+} /$ IL5- $\mathrm{R}^{+}$cells may be the earliest progenitors committed to the eosinophil lineage [3]. The IL-5 receptor is composed of an $\alpha$ subunit that only binds IL-5 and the $\beta$ chain, which is shared between the receptors for IL-3 and GM-CSF [11]. Furthermore, a high number of these cells express the eotaxin receptor CCR3 $\left(\mathrm{CD}_{3} 4^{+} / \mathrm{CCR}^{+}\right)$. It has been shown that $\mathrm{CD} 34^{+}$cells are increased in bone marrow and peripheral blood, a feature of allergic diseases, including asthma [12]. In this context, allergen exposure augments the number of $\mathrm{CD} 34^{+}$cells in asthmatic airways [13]

The fate of cells, including lineage commitment, is guided by the action of both lineage-determining and secondary transcription factors that orchestrate gene expression, cell development, and cell differentiation. In eosinophil development, common myeloid progenitors must express CCAAT/enhancer binding protein $\alpha(\mathrm{C} / \mathrm{EBP} \alpha), \mathrm{CCAAT} /$ enhancer binding protein $\varepsilon(\mathrm{C} / \mathrm{EBP} \varepsilon)$, PU.1, and interferon regulatory factor 8 (IRF8) [14].

During the process by which common myeloid progenitors mature into eosinophil progenitors, there occurs a decrease in the expression of friend of GATA-1 (FOG-1) and an increase in the expression and activity of GATA-1 transcription factor [15], as FOG-1 inhibits eosinophil differentiation [16]. GATA are a family of transcription factors that are essential for eosinophil lineage commitment, and GATA-1 and GATA-2 are specifically observed in eosinophil and mast cell differentiation $[17,18]$.

Normally, all these processes occur in the bone marrow; however, in inflamed tissues of allergic patients, local differentiation of $\mathrm{CD}_{3} 4^{+} / \mathrm{IL}-5 \mathrm{R} \alpha^{+}$cells can occur, in addition to eosinophil recruitment from bone marrow, thus promoting higher levels of eosinophilia [19]. This fact suggests that the control of $\mathrm{CD}_{3} 4^{+}$cells released from bone marrow and local differentiation of $\mathrm{CD} 34^{+} / \mathrm{IL}-5 \mathrm{R} \alpha^{+}$can control the eosinophilic inflammation associated with eosinophil development.

\section{Morphology and Characteristics of Eosinophils}

Eosinophils are terminal polymorphonuclear leukocytes with a bilobed nucleus and an $8-\mu \mathrm{m}$ diameter. After differentiation and maturation in the bone marrow, they are released into the bloodstream, where they make up about $1 \%-3 \%$ of white blood cells. Eosinophils have a limited life span; they remain in circulation for 8 to 18 hours and in tissues for 3 to 4 days [20]. Normally, these cells are resting; during the inflammatory response, however, eosinophils can be activated and release their content owing to the actions of several molecules, including cytokines, lipid mediators, and proinflammatory agents.

Eosinophils are supplied with a preformed battery of cationic granule proteins, cytokines, chemokines, growth factors, lipid mediators, and immunomodulatory molecules, as well as diverse transmembrane proteins (integrins) and surface receptors (Figure 1). Most molecules are accumulated within intracellular granules and can be released in response to certain stimuli.

\section{Eosinophil-Derived Granule Proteins}

Eosinophils play an important role in allergic and inflammatory processes, including asthma [21], and are implicated in host resistance against helminths. Moreover, they exhibit antimicrobial activity toward viral and bacterial pathogens. These functions develop through granule proteins, principally cationic granule proteins, which are necessary to resolve infections and infestations, although they are toxic to human cells [22]. Cationic granule proteins are present in the specific or secondary granules of eosinophils and include the following: major basic protein (MBP), eosinophil peroxidase (EPO), eosinophil cationic protein (ECP), and eosinophilderived neurotoxin (EDN).

MBP is abundant in the electron-dense crystalloid core of secondary granules. With its high toxicity, it can harm helminths, microbes, and mammalian cells by disrupting the cell membrane or altering enzymatic activity [23]. In the context of asthma, this protein induces bronchoconstriction and has been implicated in epithelial tissue damage [24]. MBP has 2 homologs: MBP-1 and MBP-2, the former being more potent than the latter in activities such as cell destruction, histamine induction, and leukotriene $\mathrm{C} 4$ release from basophils [25].

EPO is the most abundant cationic protein of the matrix of secondary granules, and one that generates potent oxidizing species [26]. It not only produces proinflammatory oxidants, but also plays a cytotoxic role as a cationic toxin against both parasites and mammalian cells [27]. Panagopoulos et al [28] recently discovered a new role for EPO and other peroxidase enzymes as drivers of angiogenesis.

EDN and ECP belong to the ribonuclease A superfamily and are located in the matrix of the secondary granules of 


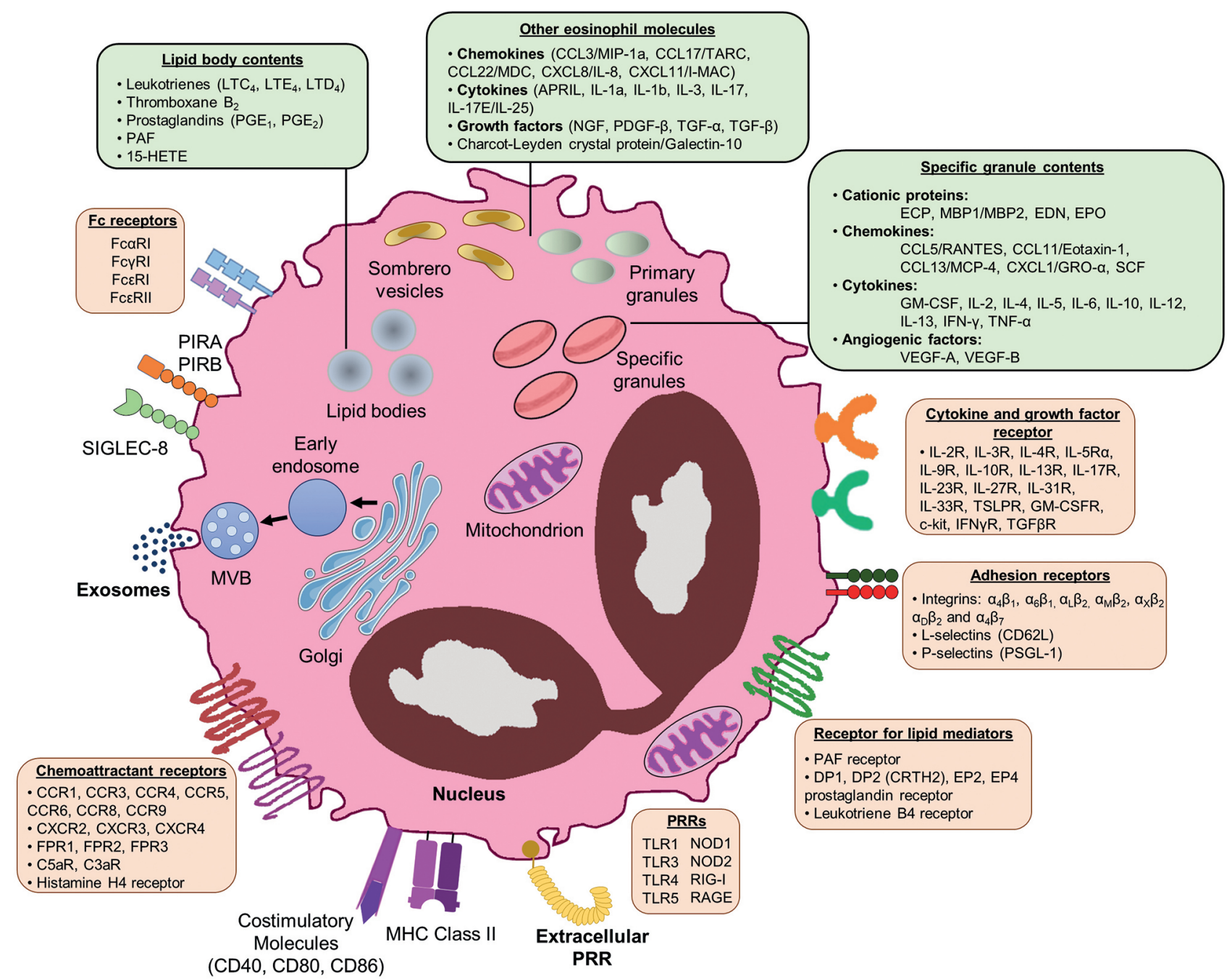

Figure 1. Molecular characteristics of eosinophils. Human eosinophils contain a high number of proteins, receptors, and enzymes that allow them to interact with the microenvironment. Some of them are released. Eosinophils are a source of cationic proteins, chemokines, cytokines, lipid mediators, and growth factors, which have a broad spectrum of action in health and disease. Primary granules store the Charcot-Leyden crystal protein/galectin-10, a characteristic eosinophil protein implicated in asthma and parasitic infections. Specific granules contain 4 principal cationic proteins: MBP, ECP, EPO, and EDN. Lipid bodies are responsible for synthetizing and releasing prostaglandins, thromboxane, and leukotrienes, which take part in allergic inflammation, fibrosis, and thrombosis. Some of the granule contents are released via membrane-bound vesicles called sombrero vesicles. Eosinophils also contain MVB, which fuse with the plasma membrane and release exosomes. Eosinophils express a broad variety of receptors implicated in activation, growth, survival, adhesion, migration, and pattern recognition. 15-HETE indicates 15-hydroxyeicosatetraenoic acid; APRIL, a proliferation-inducing ligand; CCL, CC-chemokine ligand; CCR, CC-chemokine receptor; CXCL, CXC-chemokine ligand; CXCR, CXC-chemokine receptor; ECP, eosinophil cationic protein; EDN, eosinophil-derived neurotoxin; EPO, eosinophil peroxidase; FCR, receptor of FC for immunoglobulin; FPR, formyl peptide receptor; GM-CSF, granulocytemacrophage colony-stimulating factor; IL, interleukin; IFN $\gamma$, interferon gamma; LT, leukotriene; MBP, major basic protein; MCH, major histocompatibility complex; MCP-4, monocyte chemoattractant protein-4; MVB, multivesicular body; NGF, nerve growth factor; NOD, nucleotide-binding oligomerization domain protein; PAF, platelet-activating factor; PDGF- $\beta$, platelet-derived growth factor; PG, prostaglandin; PIR, paired immunoglobulin-like receptor; PRR, pattern-recognition receptor; PSGL-1, P-selectin glycoprotein ligand 1; RAGE, receptor for advanced glycation end-products; RIG-I, retinoic acidinducible gene I; SCF, stem cell factor; SIGLEC-8, sialic acid-binding immunoglobulin-like lectin 8; TGF, transforming growth factor; TLR, Toll-like receptor; TNF, tumour necrosis factor; TSLPR, thymic stromal lymphopoietin receptor; VEGF, vascular endothelial growth factor.

eosinophils $[29,30]$. EDN has cytotoxic, neurotoxic, and antiviral (single-stranded RNA viruses) activity [31,32]; however, it shows poor toxicity for parasites and mammalian cells [31]. ECP has marked toxicity for a wide variety of helminths, bacteria, single-stranded RNA viruses, and host tissues [33].
In addition, Charcot-Leyden crystal protein/galectin-10 is another important protein located in the primary granule of eosinophils. This hydrophobic, self-crystallizing, noncationic protein accounts for about $7 \%$ and $10 \%$ of all eosinophil proteins and has been considered a potential biomarker of eosinophilic airway inflammation [34]. 


\section{Surface Markers, Receptors, Cytokines, Chemokines, and Other Mediators}

Eosinophils express a wide variety of surface receptors, molecular surface markers, cytokines, lipid mediators, and other major molecules. These are stored in numerous eosinophil granules, can be released in response to specific stimuli, and affect the microenvironment and various cell functions. Figure 1 shows the principal molecules produced by these cells.

IL-5, the chemoattractant CCL11 (eotaxin-1), and GM-CSF can exert several effects on eosinophils themselves, regulating critical functions such as eosinophil differentiation, survival, and chemotaxis [35]. In addition, eosinophils can release immunomodulatory cytokines such as IL-4, IL-13, and IL-25 [36,37], promoting $\mathrm{T}_{\mathrm{H}} 2$ responses and participating in allergic processes and immune responses against parasitic infestations [38]. Moreover, eosinophils can produce and secrete IL-6, tumor necrosis factor alpha (TNF- $\alpha$ ), and interferon-gamma $(\mathrm{IFN}-\gamma)$, which are proinflammatory cytokines that can cause tissue damage [39]. Transforming growth factor beta (TGF- $\beta$ ), which is also produced by eosinophils, improves proliferation and plays a critical role in fibrotic processes and tissue remodelling in chronic inflammatory diseases, including asthma [40]. In addition, eosinophils produce a large quantity of lipid mediators, such as prostaglandins, leukotrienes, and platelet-activating factor (PAF) [39].

Eosinophils have a broad variety of surface receptors, which allow them to interact with the microenvironment and respond to several stimuli. The main receptors expressed by eosinophils include IL-5R $\alpha$, CCR3, sialic acid-binding immunoglobulin-like lectin 8, PAF-receptor, prostaglandins (CRTH2), leukotriene B4 receptors (IL-4R, IL-5R, IL-33R, IFN- $\gamma$ R, TGF- $\beta$ R, CCR1, CCR3, CCR4, and TSLPR), crystallizable fragment of immunoglobulin $(\mathrm{Fc}) \alpha$ receptor $(\mathrm{Fc} \alpha \mathrm{R}), \mathrm{F} c \gamma \mathrm{R}$, and pattern-recognition receptors [41].

Eosinophils can also express receptors involved in $\mathrm{T}_{\mathrm{H}} 2$ immunity, such as major histocompatibility complex class II (MHCII) and costimulatory molecules such as CD40, CD80, and CD86, which are major players in eosinophil antigen presentation to stimulate T-cell proliferation, thereby initiating $\mathrm{T}_{\mathrm{H}} 2$ immune responses $[42,43]$.

Rolling along endothelium and transmigration towards tissues are regulated by coordinated action between chemokine and cytokine signaling, which augments expression of eosinophil adhesion molecules. Eosinophils express several integrins, including $\alpha 4 \beta 1$ (CD49d/CD29), $\alpha 6 \beta 1$ (CD49f/ CD29), $\alpha \mathrm{L} \beta 2$ (CD11a/CD18), $\alpha \mathrm{M} \beta 2$ (CD11b/CD18), $\alpha \mathrm{X} \beta 2$ (CD11c/CD18), $\alpha \mathrm{D} \beta 2$, and $\alpha 4 \beta 7$, which interact with their ligands including intercellular adhesion molecule 1 (ICAM-1), vascular cell adhesion molecule 1 (VCAM-1), laminin, fibronectin, and periostin located in other cells or in the extracellular matrix (reviewed in Johansson, 2014) [44]. Several studies have demonstrated the implication of these adhesion molecules in the anchoring and transmigration of eosinophils from the bloodstream to inflamed tissue $[45,46]$. VLA-4- and ICAM-1-deficient mice prevent eosinophil migration to allergic airways.

Eosinophils also express selectins, such as L-selectin (CD62L) and P-selectin glycoprotein ligand-1 (PSGL-1,
CD162), which are highly and constitutively expressed in blood eosinophils $[47,48]$.

\section{Eosinophil Subtypes}

Eosinophils have classically been described as terminally differentiated cells with uniform phenotype and function. However, this view of the eosinophil is changing. Nowadays, eosinophils are classified into subtypes based on their state of maturity, organ location, or the morphogenetic activity of tissues $[49,50]$. Thus, the local environment induces changes in eosinophil phenotype for tissue-specific functions. In addition, eosinophils in homeostasis recruited under inflammatory conditions are heterogeneous as much in function as in their surface markers. For example, eosinophils residing in the lung at baseline can play a regulatory role, whereas eosinophils recruited into the lung following allergen challenge are

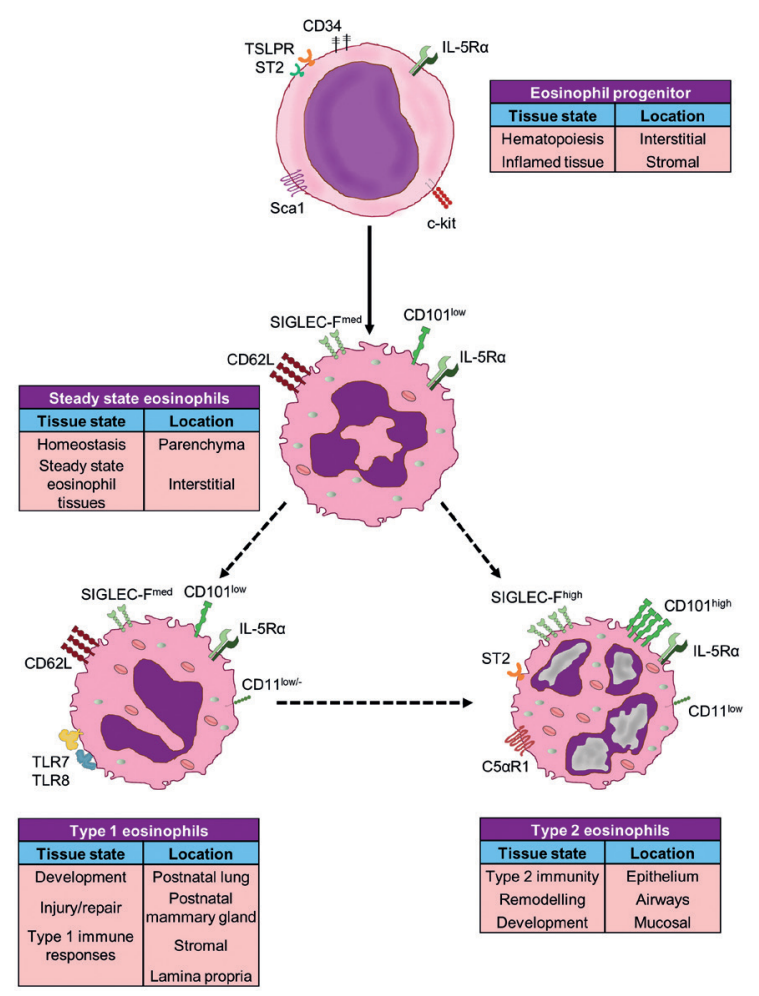

Figure 2. Tissue-based murine eosinophil subphenotypes. Murine eosinophils are divided into 4 tissue-based categories, according to shape, morphology, and tissue contexts. Eosinophil progenitor: immature eosinophils recruited as committed precursors. Steady state: resident eosinophils in true steady state found in morphogenetically quiescent tissues and characterized by their nonsegmented "donut-shape" nucleus. Type 1: usually resident in interstitial (stromal in general) in acute inflammatory, innate defense and transient morphogenetic contexts, featuring a segmented nuclear shape but without vacuolization. Type 2 : eosinophils associated with a Type 2 immune response, usually found in epithelial environments, such as murine asthmatic lungs; type 2 eosinophils have a different morphology with an extremely segmented nucleus and the presence of vacuoles. C $5 \alpha R 1$ indicated complement component 5a receptor 1 ; IL-5R $\alpha, I L-5$ receptor alpha subunit; Sca-1, stem cell antigen-1; SIGLEC-F, sialic acid binding lg-like lectins F; ST2, interleukin 33 receptor; TLR, toll-like receptor; TSLPR, thymic stroma lymphopoietin receptor. 


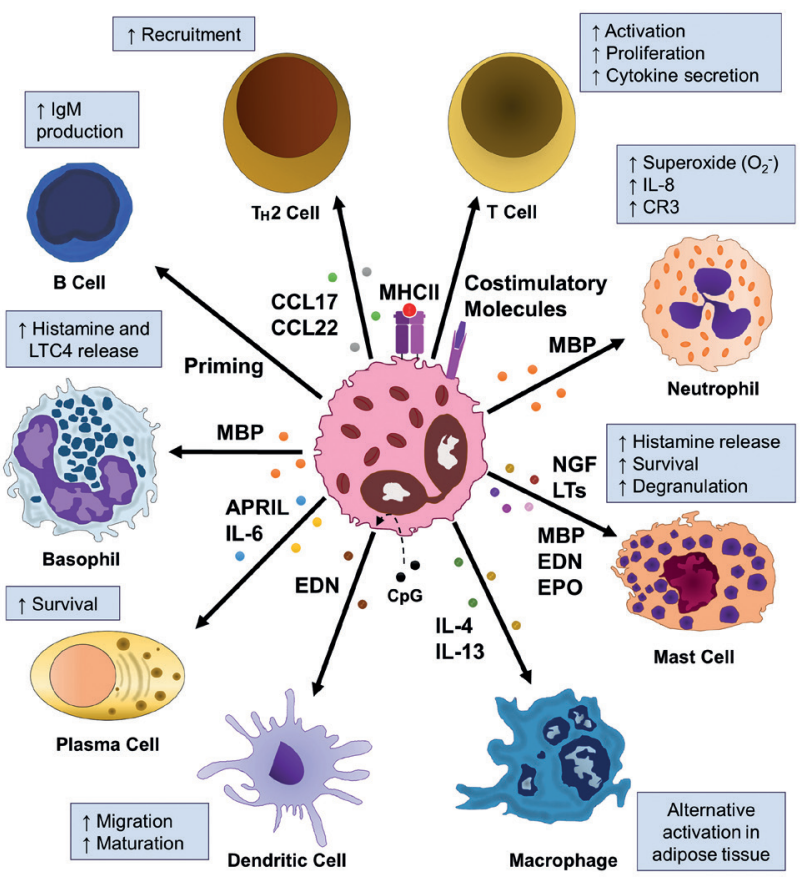

Figure 3. Modulation of leukocyte function by eosinophils. Eosinophils are able to modulate the functions of various immune cells. Eosinophils express MHCII and costimulatory molecules, process antigens, and promote proliferation and cytokine production on T cells in an antigenspecific manner. They also release CCL17 and CCL22, regulating the recruitment of $\mathrm{T}_{\mathrm{H}} 2$ cells. Eosinophils produce and release APRIL and IL-6, sustaining long-lived plasma cells in bone marrow, and priming B cells, which induces IgM secretion. Eosinophils stimulated by CpG DNA promote maturation and activation of dendritic cells, and EDN induces dendritic cell recruitment. Eosinophil-derived MBP stimulates neutrophils and basophils, causing them to secrete superoxide and IL-8 and increase CR3 expression and histamine and LT4 production, respectively. Moreover, eosinophils maintain alternatively activated macrophages in adipose tissue by IL-4 and IL-13. In mast cells, eosinophils can induce histamine release and prolong their survival by secreting MBP, EPO, EDN, NGF, and LTs. APRIL indicates a proliferation-inducing ligand; $C C L, C C$-chemokine ligand; CR3, cell-surface integrin receptor 3; EDN, eosinophil-derived neurotoxin; EPO, eosinophil peroxidase; IL, interleukin; LTs, leukotrienes; MBP, major basic protein; MHCII, major histocompatibility complex class II; NGF, nerve growth factor.

proinflammatory. Abdala-Valencia et al [51] propose 4 phenotypes (Figure 2): EoP, or immature or precursor of eosinophils; steady state, or tissues residing in quiescent tissues; Type 1, referring to interstitial eosinophils in acute inflammatory, innate defense, and transient morphogenetic contexts; and Type 2, eosinophils associated with a type 2 immune response.

Future studies are needed to clarify the diversity of eosinophils and their therapeutic modulation.

\section{Interaction Between Eosinophils and Other Cells}

Eosinophils are multifunctional cells implicated in multiple processes and, as such, can interact with a variety of cell types. They can interact with other leukocytes and modulate their functions (Figure 3); for example, they can induce antigenspecific IgM production by priming B cells and sustain long-lived plasma cells in the bone marrow by secreting a proliferation-inducing ligand (APRIL) and IL-6 [52].

It has been widely observed that eosinophils respond to diverse signals from $\mathrm{T}$ cells (such as IL-5), although T cells can also respond to signals provided by eosinophils [53]. Eosinophils can process antigens and act as antigen-presenting cells [54]. Moreover, eosinophils can contribute to the adaptive immune response by producing chemoattractants such as EDN, CCL17, CCL22, CXCCL9, and CXCL10, which recruit dendritic cells and $\mathrm{T}_{\mathrm{H}} 2$ cells $[55,56]$, and CpG-DNA-stimulated eosinophils bring about dendritic cell maturation [57].

Historically, eosinophils and mast cells have been considered the principal cells in allergic inflammation, and both can interact via soluble mediators and physical contact [58-61]. Furthermore, eosinophils can indirectly activate mast cells [62], neutrophils [63], basophils [25], and macrophages in adipose tissue [64].

\section{Eosinophil Degranulation}

In response to various stimuli, eosinophils are recruited from peripheral blood to the area of inflammation, where their effects take place and where they modulate the inflammatory response through the release of granule-derived content $[65,66]$.

There are 3 known types of degranulation in eosinophils: exocytosis, piecemeal degranulation, and cytolytic degranulation. In the first case, intracellular granules fuse with the plasma membrane and release the total granule content (classical exocytosis). In the variant of classical exocytosis called compound exocytosis, individual granules fuse with each other before fusing with the plasma membrane and releasing granules into the extracellular space [67]. Harmful stimuli, the presence of parasitic helminths [68], and specific environmental conditions such as presence of fungi [69] generate this pattern of secretion. However, this type of degranulation is not very common in other scenarios where eosinophils act.

Piecemeal degranulation is associated with cytoplasmic vesiculation [70]. The mechanism is based on packaging of the contents of cytoplasmic granules in small secretory vesicles, named sombrero vesicles, which are transported into the cellular membrane through tubulovesicular structures that act as vesicular carriers to fuse with the cellular membrane, thus releasing their contents into the extracellular space [71]. This is a carefully regulated mechanism, and the most common physiological process [72-74]. Piecemeal degranulation is induced by cytokines and chemokines such as IFN- $\gamma$ [75], CCL-11 (eotaxin-1), and TNF- $\alpha$ [76]. Discharge of granule content does not imply the death of the eosinophils, which remain fully functional and able to respond to other stimuli after piecemeal degranulation. This mechanism is not exclusive of eosinophils, as has also been established in mast cells and basophils [77].

In cytolytic degranulation, intact intracellular granules are released through specific eosinophil cell death that 
is morphologically different from both apoptosis and necrosis [78]. This type of eosinophilic cell death known as ETosis ("extracellular trap cell death"), involves the disintegration of the nuclear membrane and DNA decondensing into the surrounding cytoplasm. The secreted granules are fully competent.

Although piecemeal degranulation is the most common type of eosinophil degranulation, cytolysis takes place in a smaller proportion [79] and is typically associated with augmented inflammatory effects of eosinophils.

Despite the fact that eosinophils exert their effects through degranulation, this process does not take place when eosinophils are in blood circulation. As a result, in several conditions mediated by eosinophils, they do not release their granules until they have reached the inflamed tissue $[80,81]$.

\section{Eosinophilic Exosomes}

There is considerable vesicular traffic within eosinophils, and some of these granules may be endosomes and multivesicular bodies (MVB), which are characteristic of exosome biogenesis.

Exosomes are small vesicles that contain bioactive lipids, nucleic acid, and proteins, which are delivered to different locations in the body. Intercellular communication appears to be one of the most important functions of exosomes. They also have specific molecules related to their biogenesis, enabling them to be characterized (exocarta.org/exosome_markers). Exosomes have been defined by their size, density, and expression of specific biomarkers (eg, tetraspanins). Exosomes are secreted, constitutively and upon stimulation, by different types of cells; consequently, their composition differs depending on their cellular origin.

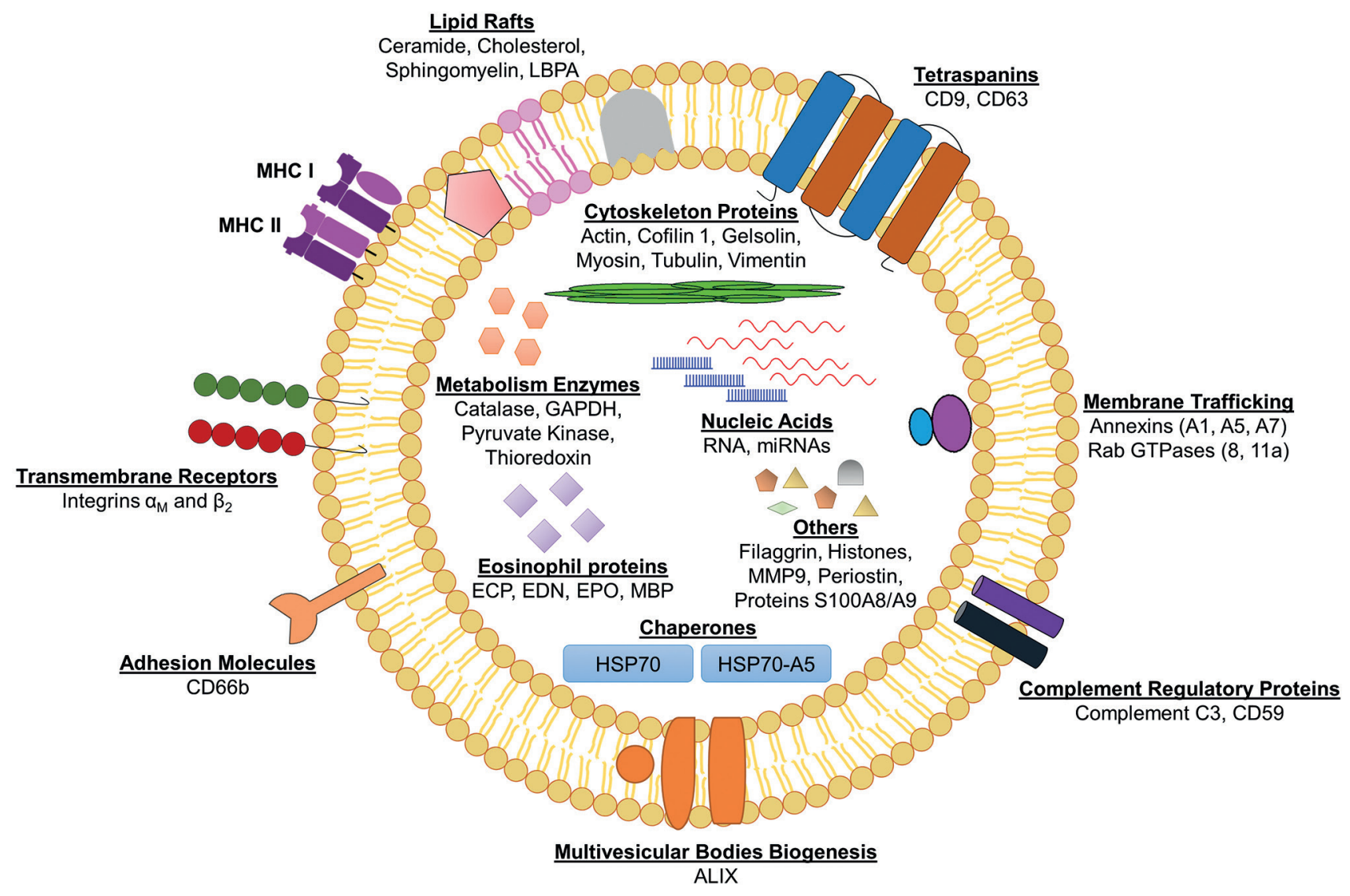

Figure 4. Typical structure and molecular composition of an eosinophil-derived exosome. Exosomes contain a wide range of molecules, including proteins, lipids, mRNAs, and miRNAs. The contents of exosomes can be transferred from their cells of origin to target cells involved in intercellular communication. The exosomes released by eosinophils carry out specific functions in asthma as a result of their protein composition. These exosomes carry several proteins involved in antigen presentation (MHC I and II), proteins involved in targeting and adhesion (tetraspanins, integrins, adhesion molecules), cytoskeleton proteins (actin, tubulin, gelsolin, myosin), MVB biogenesis and secretion-associated proteins (ALIX, annexins, Rab GTPases), chaperone proteins (HSP70, HSP70-A5), metabolic enzymes (catalase, pyruvate kinase, GAPDH), eosinophil-cationic proteins (MBP, EPO, EDN and ECP), and other proteins (periostin, filaggrin, histones and S100 proteins). They also contain lipid rafts composed by ceramide, cholesterol, sphingomyelin and LBPA. ECP indicates eosinophil cationic protein; EDN, eosinophil-derived neurotoxin; EPO, eosinophil peroxidase; GAPDH, glyceraldehyde 3-phosphate dehydrogenase; HSP, heat shock protein; LBPA, lysobisphosphatidic acid; MBP, major basic protein; MHC I, major histocompatibility complex class I; MHC II, major histocompatibility complex class II; miRNAs, microRNAs; MMP9, matrix metalloproteinase 9. 
Eosinophils contain MVBs (exosome precursors) and are capable of secreting exosomes into the extracellular environment [82]. Exosome eosinophils carry characteristic eosinophil proteins such as major basic protein (MBP) and eosinophil peroxidase (EPO), tetraspanins (CD9, CD63), MVB biogenesis proteins (ALIX), and metabolomic enzymes (catalase, pyruvate kinase, GAPDH) [82] (Figure 4). Proteome profiling of exosomes from eosinophils established almost 100 different proteins [83] linked to multiple process and mechanisms such as immune response, inflammation, migration, cell signaling, and specific eosinophil granule proteins.

This finding supports the hypothesis that exosomes can act as independent functional units, perpetuating the inflammatory damage generated by eosinophils even after these cells are not present. We demonstrated that exosomes from eosinophils act on structural lung cells to produce epithelial damage, increase smooth muscle proliferation, and modify the expression of several proinflammatory cytokines and signaling factors [84].

\section{Eosinophil Involvement in Asthma and Allergy}

\section{Eosinophil Recruitment and Survival: Key Steps in the Pathophysiology of Allergic Asthma}

Alterations in eosinophil function and homeostasis have been linked to the pathogenesis of asthma since 1988, when an elevation in eosinophil number and in the levels of eosinophilic MBP was described in the bronchoalveolar lavage fluid of mild asthmatics [85].

Since this discovery, allergic asthma has been characterized by airway obstruction, bronchial hyperresponsiveness, and inflammation of the airway, where eosinophils play a key role in damaging the epithelium and orchestrating an immune response [86]. In eosinophilic asthma, also described as $\mathrm{T}_{\mathrm{H}} 2$ asthma, the rise in the number of eosinophils in the airways starts when the airway epithelium is exposed to an allergen or antigen, thus causing the activation of an immunological cascade that drives eosinophils to the airways by $\mathrm{T}_{\mathrm{H}} 2$ cytokines and chemoattractants [87]. When helper T cells are activated by an allergen, they skew to the $\mathrm{T}_{\mathrm{H}} 2$ phenotype and start to secrete IL-4, IL-5, and IL-13 [88,89]. IL-5 and RANTES have been reported to be the most potent inducers of eosinophil migration into the asthmatic lung [90]. The airway epithelium is also involved in the secretion and production of these $\mathrm{T}_{\mathrm{H}} 2$ cytokines by secreting another set of cytokines that promote the $\mathrm{T}_{\mathrm{H}} 2$ immune response, such as IL-33, TSLP, and IL-25, which are secreted in the event of epithelial insult of any type [91-93]. These epithelial cytokines also activate type 2 innate lymphoid cells from the innate immune system, which also secrete and produce IL-4, IL-13, and IL-5 [94]. These may be the first cells involved in eosinophil recruitment, as recently described by Chen et al [94], since they were the first to experience an increase in the sputum of asthmatic patients 24 hours after allergen exposure and their levels correlated with eosinophil levels at all time points [94].

All secreted $\mathrm{T}_{\mathrm{H}} 2$ cytokines are involved in eosinophil recruitment, migration, or survival and are responsible for the increased eosinophil numbers in bronchoalveolar lavage fluid as described in 1988 [85]. IL-4 promotes eosinophil migration by inducing epithelial expression of VCAM-1 and eotaxin and induces the isotype switch to IgE in B lymphocytes [95]. Specifically, eosinophils bind to vascular endothelial VCAM-1 by its binding molecule, VLA-4 [96]. Both IL-5 and eotaxin promote the release of eosinophils from the bone marrow; specifically, IL-5 promotes survival and migration, and the eotaxin enhances migration by binding to CCR3 expressed on the eosinophil surface $[97,98]$. Within the eotaxin group, we should differentiate between eotaxin-1 (CCL11), which binds to CCR3, as described above, and eotaxin-3 (CCL26), which plays a key role in eosinophil recruitment in eosinophilic esophagitis, where it is highly upregulated in the esophagus [99]. Expression of CCR3 is expressed in eosinophils, but not on the surface of neutrophils, which is one of the reasons behind eosinophilic recruitment when eotaxin-1 is overexpressed in $\mathrm{T}_{\mathrm{H}}$ 2-type diseases [100]. Alongside IL-5, IL-3 and GM-CSF are known mediators of eosinophil survival in the airways and perform a key role in their differentiation and migration processes [101].

Lipids such as leukotrienes and prostaglandins are also important mediators of inflammation. Eosinophils are attracted to the airways by leukotrienes, such as leukotriene E4, and PAF [102-104]. In addition, prostaglandin D2 has been described as a chemoattractant of eosinophils, as it binds to the receptor CRTH2 in eosinophils, also known as DP2, thus inducing its recruitment and activation [105].

Several studies have determined the number of eosinophils in the airways as a biomarker for asthma, even showing a correlation with the level of airway hyperresponsiveness and disease severity, as measured in samples such as sputum or peripheral blood $[106,107]$. The recruitment phase is followed by the effector phase. When activated, eosinophils can promote their own survival capacity in the tissues by autocrine secretion of IL-5, which inhibits apoptosis, and by secreting GM-CSF and IL-3 when eosinophils adhere to fibronectin, thus revealing why eosinophils survive at inflammatory sites [20,108]. Therefore, adding the effect of both cytokines released through autocrine secretion by eosinophils allows them to remain in the tissue and exert their effect for long periods.

\section{Activated Eosinophils Contribute to Asthma Hallmarks}

Asthma phenotype is biologically explained by a dysfunction in airway homeostasis. This is provoked by epithelial damage, mucus secretion, and muscle hypertrophy, all leading to a state of airway hyperresponsiveness triggered by exposure to an antigen. Eosinophils are one of the most highly implicated cells in the development of these events. First, they damage the airway epithelium by releasing hazardous molecules. Previously described enzymes secreted by eosinophils such as MBP, EPO, and ECP can damage epithelial cells in vitro when administered in doses similar to those found in asthmatic sputum $[109,110]$. Upon activation by TNF- $\alpha$, an upregulated molecule found at the sites of inflammation, eosinophils secrete matrix metalloproteinase-9, an enzyme implicated in airway remodelling and a hallmark of asthma [111]. Airway remodelling is a process that can 
occur physiologically, but also pathologically, as in asthma, with epithelial barrier disruption, goblet cell hyperplasia, and membrane thickening and fibrosis, accompanied by airway smooth muscle hyperplasia or hypertrophy and increased formation of new blood vessels (angiogenesis). Enzymes secreted by eosinophils have been reported to contribute to tissue disruption, although some studies have shown that eosinophils also induce muscle cell proliferation and collagen deposition in mice, whereas an eosinophil-depleted model did not [21]. Another molecule that is secreted by eosinophils and regulates airway remodelling is TGF- $\beta$, which, according to biopsy samples from patients with severe asthma, is upregulated in mRNA and correlates with the thickness of the basement membranes [112]

Inorganic chemicals are also released by eosinophils, and these have various effects on receptor tissue. Nitric oxide (NO) is a mediator of inflammation and has been described as another recruiter of eosinophils when synthesized by the inducible nitric oxide synthase enzyme in vascular endothelial cells and epithelial cells and is correlated with levels of exhaled nitric oxide, a biomarker of asthma [113,114]. Besides structural cells such as endothelial or epithelial cells, one of the major producers of NO are eosinophils, which also secrete reactive oxygen species (ROS) such as superoxide anion, hydroxyl radicals, and hydrogen peroxide, as previously described, which are implicated in the pathogenesis of asthma by contributing to airway injury and inflammation $[115,116]$.

Lipid mediators, in addition to promoting eosinophil migration, are molecules that are released by eosinophils and include lipoxin A4, thromboxane B2, prostaglandin E2, and cysteinyl leukotrienes, and can thus modulate the immune response by adding these molecules to the refinement of

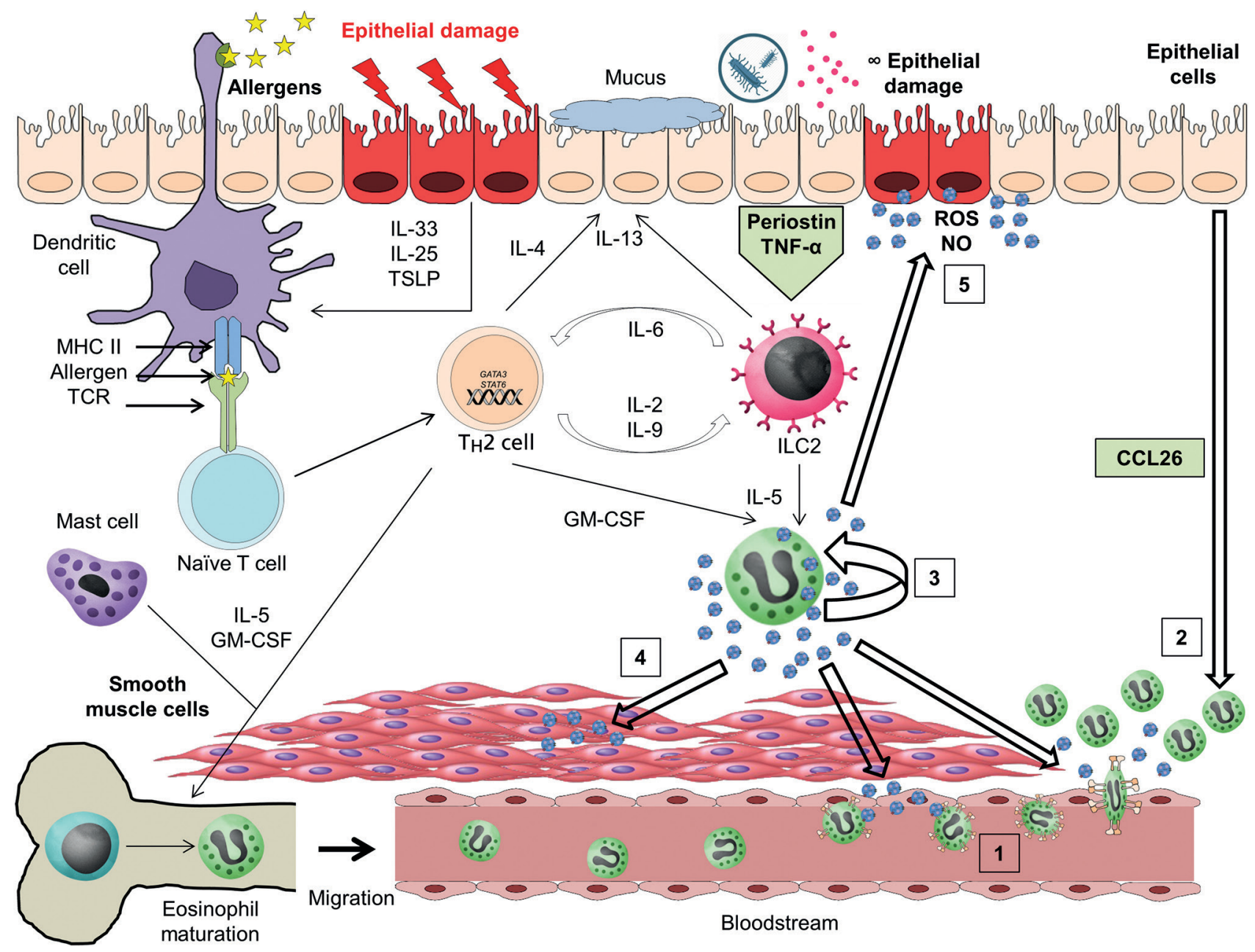

Figure 5. Eosinophil involvement in asthma and allergy. Eosinophils perform their effector functions when an immune response is orchestrated. Allergens activate the epithelium of the airways that secrete cytokines such as IL-33, IL25, or TSLP, which will activate ILC2 to secrete pro-eosinophilic recruitment molecules such as IL4-IL5 and IL-13. Dendritic cells process the allergen and activate $T_{H} 2$ CD4+ cells that promote eosinophil recruitment through the production of IL-4, IL-5, GM-CSF, RANTES, and IL-13. The recruitment of eosinophils is also promoted directly in the epithelium by endothelial cells, epithelial cells, and fibroblasts, as well as by secreting molecules such as periostin and eotaxin. Eosinophil survival and activation is promoted by IL-5 produced by immune cells, but also through autocrine secretion by eosinophils. Once recruited and activated, eosinophils perform their immune functions inappropriately, targeting the airways, secreting the toxic and enzymatic content of their granules (ECP, MPB, NO, ROS, MMP9), causing damage, and secreting exosomes that impair wound healing by increasing apoptosis. Airway remodeling is associated with muscle cell hyperplasia, which is activated by TGF- $\beta$ and exosomes secreted by eosinophils. All these features are behind the role of eosinophils in $T_{H} 2$ immune disease. 
immunologic reactions [117]. Within the group of lipids that promote restoration of cell function after inflammation, resolvins have been the most widely studied in asthma. Eosinophils secrete resolvin E3, an anti-inflammatory mediator that inhibits neutrophil chemotaxis both in vivo and in vitro [118].

In summary, eosinophils secrete exosomes that can act both in an autocrine fashion on themselves, thus increasing their capacity for producing NO and ROS species, and in an exocrine fashion, by releasing the exosomes onto the airway epithelium. In asthma, they reduce the repair capacity of the epithelium by elevation of apoptosis rates and increasing the proliferation of muscle cells, indicating that eosinophils also contribute to airway remodelling by exosome release $[83,84]$.

\section{Pathophysiology of Eosinophils in Allergic Diseases and Other $T_{H} 2$ Disorders}

As mentioned above, eosinophil migration is dependent on various molecules such as cytokines released by $\mathrm{T}_{\mathrm{H}} 2$ cells (IL-4, IL-5, IL-13, RANTES), which are mainly released when T-cells interact with antigen-presenting cells. Eosinophil migration targets the tissue site where the immune reaction takes place. Eosinophils are also attracted to the esophagus in eosinophilic esophagitis, where eotaxin-3 (CCL26) principally recruits eosinophils, which damage the epithelium and activate it, as occurs in the pathogenesis of asthma [119]. The esophageal epithelium then induces gene expression of molecules that regulate its own barrier function, such as filaggrin and periostin. These molecules, and in particular periostin, have also been studied in asthma, and it has been shown that periostin is upregulated both in asthmatic and in eosinophilic esophagitis patients and that filaggrin is downregulated in eosinophilic esophagitis biopsies [120,121]. Periostin has been studied as a key regulator for the infiltration of eosinophils into the lungs and esophagus of allergic mice, as described in a null model for the periostin gene [122]. Atopic dermatitis behaves in a similar fashion. Atopy is defined as an allergic predisposition that is inheritable; it is responsible for less than half of all asthma cases [123]. In atopic dermatitis, the allergen is exposed principally to the skin, at which point fibroblasts secrete periostin, which in turn activates keratinocytes, which secrete cytokines such as TSLP and others, skewing to a $\mathrm{T}_{\mathrm{H}} 2$ response and recruiting eosinophils into the epithelium [124].

Other kinds of allergic and asthmatic diseases that are more allergen- or trigger-specific are also characterized by eosinophil recruitment and involvement. Infection with Aspergillus fumigatus may be followed by a type of allergy known as allergic bronchopulmonary aspergillosis, where sensitization to Aspergillus species can induce an allergic response that is also mediated by eosinophils [125]. In aspirin-related disease, hypersensitivity to nonsteroidal anti-inflammatory drugs is developed after deregulation in arachidonic acid metabolism that occurs under the effect of aspirin, thus triggering a dramatic

Table. Examples of Agents Targeting Eosinophils

\begin{tabular}{|c|c|c|c|}
\hline Target & Mechanism of action & Examples/Drugs & Ref \\
\hline \multicolumn{4}{|c|}{ Blockade of eosinophil recruitment } \\
\hline CCR3 & Antagonist/Inhibition & GW766994, Ki19003 & 147,148 \\
\hline CCL11 & Blocks eotaxin-1 & Bertilimumab & 149 \\
\hline CD49d & $\begin{array}{l}\text { Blocks CD49D specific mAb or } \\
\text { small-molecule VLA4 antagonists }\end{array}$ & Natalizumab, TR14035 & $150-152$ \\
\hline CRTH2 & CRTH2 Antagonist & OC000459 & 153,154 \\
\hline H4R & H4R Antagonists & INCB38579, UR-63325 & 155,156 \\
\hline IL-4 & Blocks IL-4 & Altrakincept & 157 \\
\hline IL-13 & Blocks IL-13 & Lebrikizumab, anrukinzumab & $158-160$ \\
\hline IL-4R $\alpha /$ IL-13R $\alpha$ & Inhibits binding of IL-4 and/or IL-13 to IL-4R $\alpha$ & Pitrakinra, AMG317, dupilumab & $160-165$ \\
\hline \multicolumn{4}{|c|}{ Inhibition of eosinophil survival } \\
\hline IL-5 & Blocks IL-5 & Mepolizumab and reslizumab & $166-168$ \\
\hline IL-5R $\alpha$ & Inhibits binding of IL-5 to IL-5R & & \\
\hline \multicolumn{2}{|c|}{ ADCC against eosinophils } & Benralizumab & 169 \\
\hline Siglec-8 & Agonism & Anti-Siglec- $8 \mathrm{mAb}$ & 170,171 \\
\hline $\operatorname{IgE}$ & Binds free IgE & Omalizumab & $172-174$ \\
\hline EMR1 & & Afucosylated anti-EMR1 mAb & 175 \\
\hline TSLP & Antagonism & Tezepelumab & 176 \\
\hline \multicolumn{4}{|c|}{ Inhibition of eosinophil activation } \\
\hline Notch & Inhibition & Semagacestat & 177 \\
\hline CD52 & & Alemtuzumab & 178 \\
\hline
\end{tabular}


rise in eosinophils and the onset of asthma [126]. Finally, occupational asthma is another kind of asthma disease, where exposure to a specific compound occurs repeatedly over a prolonged period of time, normally on a daily basis, as in the workplace. It has been reported that $90 \%$ of occupational asthma cases are characterized by eosinophil infiltration and high IgE levels [127].

A visual representation of the role of eosinophils and their exosomes in asthma and allergy is shown in Figure 5.

\section{Eosinophilic Disorders}

Eosinophils accumulate for reasons other than allergen exposure. In acute idiopathic eosinophilic pneumonia, eosinophils accumulate and damage the airways by means of a currently unclear mechanism that may be related to clonal T cells [128]. Chronic eosinophilic pneumonia has also been described, although compared with the acute disorder, the chronic form is often associated with previous asthma or atopy $[88,129]$. Pulmonary fibrosis is also caused by the accumulation of eosinophils, although in this case it is accompanied by neutrophils, and its pathophysiology is caused by interstitial collagen deposition, which leads to fibrosis $[88,130]$. Eosinophilia has also been associated with hematologic malignancies and is less common with solid tumors [131]. Finally, hypereosinophilic syndromes are a heterogeneous group of diseases with an elevated number of eosinophils in blood or other tissues in which the manifestations vary depending on where the eosinophilia are found [132].

\section{Targeting Eosinophils}

Targeting eosinophilia may help to control several diseases associated with eosinophils (eg, asthma, allergy, eosinophilic esophagitis, hypereosinophilic syndromes). Eosinophils provide an ideal target for biological treatment owing to expression of specific surface receptors on their membranes and because evidence from eosinophil-deficient mouse models and case reports in humans without eosinophils suggest that eosinophil depletion has little effect on immunity to infection and other essential host defense mechanisms.

Historically and nowadays, corticosteroids are one of the most effective drugs used to reduce eosinophil count and, consequently, eosinophil-mediated damage. Similar to the pleiotropic effects on other leukocytes, these drugs cause eosinophil apoptosis [133], although long-term toxicity and persistent eosinophilia, even after treatment with oral corticosteroids, limit their therapeutic use. Clearly, effective alternative therapies are needed. Therefore, current therapies are moving forward to control eosinophils by means of approaches based on blocking the recruitment and migration of eosinophils into tissues, impairment of the survival of mature eosinophils, blocking of eosinophil production in bone marrow, and inhibition of eosinophil activation (Table).

As the development of eosinophilic inflammation is dependent on the activity of IL-5, biologicals targeting IL-5 are an obvious therapeutic option (Figure 6). Two different humanized IL-5-specific antibodies (ie, mepolizumab and

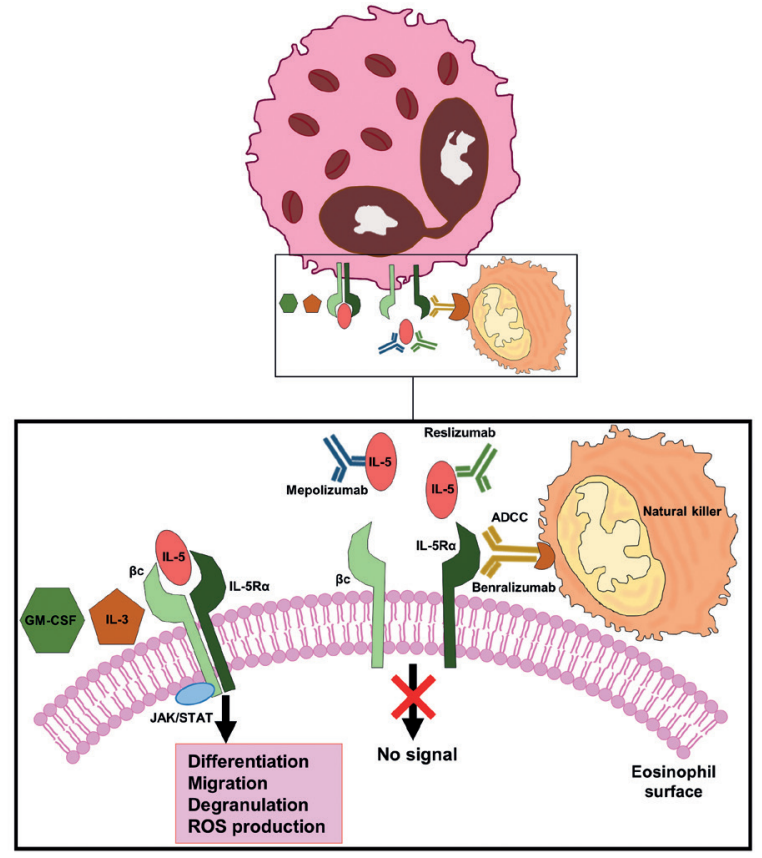

Figure 6. Antibody-based treatment blocking eosinophil functions. IL-5 plays a critical role in eosinophil development and differentiation, maturation in bone marrow, and migration at inflammatory sites. The interaction between IL-5 and its receptor (IL-5R) induces eosinophil degranulation and release of granule proteins and increases the respiratory burst, thus generating reactive oxygen species (ROS). IL-3 and GM-CSF only interact with the $\beta C$ subunit of IL-5R. Anti-IL-5 therapies based on monoclonal antibodies (mepolizumab and reslizumab) block binding of IL-5 to IL-5R a located on the eosinophil surface. Benralizumab is a humanized monoclonal antibody that binds to IL-5R $\alpha$, thus enhancing ADCC. Natural killer cells bind to anti-IL-5R $\alpha$ antibody through FCR and improve eosinophil-depleting activity. ADCC indicates antibodydirected cell cytotoxicity; $\beta c$, beta chain subunit; $F C R$, receptor of $F c$ for immunoglobulin; GM-CSF, granulocyte macrophage colony-stimulating factor; IL, interleukin; IL-5R, IL-5 receptor; IL-5R $\alpha$, IL-5 receptor alpha subunit.

reslizumab) have been developed and tested in clinical trials for asthma and other eosinophilic disorders [134-136]. Early trials using anti-IL-5 (mepolizumab and reslizumab) were largely unsuccessful until researchers recognized the need to quantify eosinophils in asthma patients in order to identify those in whom these medications would be more effective. Recent trials reported efficacy in eosinophilic asthma, and both drugs have received market authorization [137-142]. Similarly, another attractive therapeutic approximation includes the IL-5 receptor (IL-5R), which is composed of $\alpha$ and $\beta$ subunits and expressed on the surface of eosinophils, eosinophil progenitors $\left(\mathrm{CD} 34^{+}\right)$, mast cells, and basophils [143]. Benralizumab is an anti-IL$5 \mathrm{R} \alpha$ antibody that leads to the interruption of IL-5R-mediated signal transduction and is afucosylated, thus improving antibody-dependent, cell-mediated cytotoxicity [144]. It is effective in eliminating eosinophils in both serum and tissue $[145,146]$

Future challenges should include determining which eosinophil-reducing treatment is more effective and safe for patients with disorders associated with eosinophils. 


\section{Conclusion}

Eosinophils perform a critical role in asthma, allergic reactions, and atopic dermatitis, where they are attracted to the affected site and carry out their toxic functions. The increasing interest in eosinophils owing to the development of new biological treatments is generating new challenges in research in this field.

\section{Acknowledgments}

The authors are grateful to Oliver Shaw, English editor of IIS-FJD, for his revision and editing in English

\section{Funding}

This study was supported by Fondo de Investigación Sanitaria - FIS [PI15/00803, FI16/00036], the Merck Health Foundation, CIBER de Enfermedades Respiratorias (CIBERES), a Carlos III Institute of Health initiative, the Conchita Rábago Foundation (FCR), and FEDER funds.

\section{Conflicts of Interest}

VdP has been a consultant/speaker for AstraZeneca. The remaining authors declare that they have no conflicts of interest.

\section{References}

1. Huber HL, Koesler KK. The pathology of bronchial asthma. Arch Int Med. 1922;30:689-760.

2. Radonjic-Hösli S, Simon H-U. Eosinophils. Chem Immunol Allergy. 2014;100:193-204.

3. Mori Y, Iwasaki H, Kohno K, Yoshimoto G, Kikushige Y, Okeda $A$, et al. Identification of the human eosinophil lineagecommitted progenitor: revision of phenotypic definition of the human common myeloid progenitor. J Exp Med. 2009;206:183-93

4. Rådinger $M$, Lötvall J. Eosinophil progenitors in allergy and asthma - do they matter? Pharmacol Ther. 2009;121:174-84.

5. Sehmi R, Denburg JA. Differentiation of human eosinophils. Role in allergic inflammation. Chem Immunol. 2000;76:2944.

6. Foster PS, Hogan SP, Ramsay AJ, Matthaei KI, Young IG. Interleukin 5 deficiency abolishes eosinophilia, airways hyperreactivity, and lung damage in a mouse asthma model. J Exp Med. 1996;183:195-201.

7. Kopf M, Brombacher F, Hodgkin PD, Ramsay AJ, Milbourne EA, Dai WJ, et al. IL-5-Deficient Mice Have a Developmental Defect in CD5+ B-1 Cells and Lack Eosinophilia but Have Normal Antibody and Cytotoxic T Cell Responses. Immunity. 1996:4:15-24.

8. Hui CC, Rusta-Sallehy S, Asher I, Heroux D, Denburg JA. The effects of thymic stromal lymphopoietin and IL-3 on human eosinophil-basophil lineage commitment: Relevance to atopic sensitization. Immun Inflamm Dis. 2014;2:44-55.

9. Johnston LK, Hsu CL, Krier-Burris RA, Chhiba KD, Chien KB, McKenzie A, et al. IL-33 Precedes IL-5 in Regulating Eosinophil
Commitment and Is Required for Eosinophil Homeostasis. J Immunol. 2016;197:3445-53.

10. Sehmi R, Wood LJ, Watson R, Foley R, Hamid Q, O'Byrne $\mathrm{PM}$, et al. Allergen-induced increases in IL-5 receptor alphasubunit expression on bone marrow-derived CD34+ cells from asthmatic subjects. A novel marker of progenitor cell commitment towards eosinophilic differentiation. J Clin Invest. 1997; 100:2466-75.

11. Kotsimbos AT, Hamid Q. IL-5 and IL-5 receptor in asthma. Mem Inst Oswaldo Cruz. 1997;92 Suppl 2:75-91.

12. Sehmi R, Baatjes AJ, Denburg JA. Hemopoietic progenitor cells and hemopoietic factors: potential targets for treatment of allergic inflammatory diseases. Curr Drug Targets Inflamm Allergy. 2003;2:271-8.

13. Sergejeva $S$, Johansson AK, Malmhäll C, Lötvall J. Allergen exposure-induced differences in CD34+ cell phenotype: relationship to eosinophilopoietic responses in different compartments. Blood. 2004;103:1270-7.

14. Fulkerson PC. Transcription Factors in Eosinophil Development and As Therapeutic Targets. Front Med. 2017;4:115.

15. Du Roure C, Versavel A, Doll T, Cao C, Pillonel V, Matthias G, et al. Hematopoietic overexpression of FOG1 does not affect B-cells but reduces the number of circulating eosinophils. Coen L, editor. PLoS One. 2014;9:e92836.

16. Querfurth E, Schuster M, Kulessa H, Crispino JD, Döderlein $G$, Orkin SH, et al. Antagonism between C/EBPbeta and FOG in eosinophil lineage commitment of multipotent hematopoietic progenitors. Genes Dev. 2000;14:2515-25.

17. Zon LI, Yamaguchi Y, Yee K, Albee EA, Kimura A, Bennett JC, et al. Expression of mRNA for the GATA-binding proteins in human eosinophils and basophils: potential role in gene transcription. Blood. 1993;81:3234-41.

18. Hirasawa R, Shimizu R, Takahashi S, Osawa M, Takayanagi S, Kato $Y$, et al. Essential and instructive roles of GATA factors in eosinophil development. J Exp Med. 2002;195:1379-86.

19. Robinson DS, Damia R, Zeibecoglou K, Molet S, North J, Yamada T, et al. CD34 + /Interleukin-5R a Messenger RNA + Cells in the Bronchial Mucosa in Asthma: Potential Airway Eosinophil Progenitors. Am J Respir Cell Mol Biol. 1999;20:9-13.

20. Walsh GM. Eosinophil apoptosis and clearance in asthma. J Cell Death. 2013;6:17-25.

21. Humbles AA, Lloyd CM, McMillan SJ, Friend DS, Xanthou G, McKenna $E E$, et al. A critical role for eosinophils in allergic airways remodeling. Science. 2004;305:1776-9.

22. Hogan SP, Rosenberg HF, Moqbel R, Phipps S, Foster PS, Lacy $P$, et al. Eosinophils: Biological Properties and Role in Health and Disease. Clin Exp Allergy. 2008;38:709-50.

23. Gleich GJ, Adolphson CR, Leiferman KM. The biology of the eosinophilic leukocyte. Annu Rev Med. 1993;44:85-101.

24. Gundel RH, Letts LG, Gleich GJ. Human eosinophil major basic protein induces airway constriction and airway hyperresponsiveness in primates. J Clin Invest. 1991;87:14703.

25. Sarmiento EU, Espiritu BR, Gleich GJ, Thomas LL. IL-3, IL-5, and granulocyte-macrophage colony-stimulating factor potentiate basophil mediator release stimulated by eosinophil granule major basic protein. J Immunol. 1995; 155:2211-21.

26. Wang J-G, Mahmud SA, Thompson JA, Geng J-G, Key NS, Slungaard A. The principal eosinophil peroxidase product, 
HOSCN, is a uniquely potent phagocyte oxidant inducer of endothelial cell tissue factor activity: a potential mechanism for thrombosis in eosinophilic inflammatory states. Blood. 2006:107:558-65.

27. Auriault C, Capron M, Capron A. Activation of rat and human eosinophils by soluble factor(s) released by Schistosoma mansoni Schistosomula. Cell Immunol. 1982;66:59-69.

28. Panagopoulos V, Zinonos I, Leach DA, Hay SJ, Liapis V, Zysk A, et al. Uncovering a new role for peroxidase enzymes as drivers of angiogenesis. Int J Biochem Cell Biol. 2015;68:128-38.

29. Rosenberg HF, Ackerman SJ, Tenen DG. Human eosinophil cationic protein. Molecular cloning of a cytotoxin and helminthotoxin with ribonuclease activity. J Exp Med. 1989;170:163-76.

30. Rosenberg HF, Tenen DG, Ackerman SJ. Molecular cloning of the human eosinophil-derived neurotoxin: a member of the ribonuclease gene family. Proc Natl Acad Sci U S A. 1989;86:4460-4.

31. Domachowske JB, Dyer KD, Bonville CA, Rosenberg HF. Recombinant human eosinophil-derived neurotoxin/RNase 2 functions as an effective antiviral agent against respiratory syncytial virus. J Infect Dis. 1998;177:1458-64.

32. Sorrentino S, Glitz DG, Hamann KJ, Loegering DA, Checkel JL, Gleich GJ. Eosinophil-derived neurotoxin and human liver ribonuclease. Identity of structure and linkage of neurotoxicity to nuclease activity. J Biol Chem. 1992;267:14859-65.

33. Rosenberg HF. Recombinant human eosinophil cationic protein. Ribonuclease activity is not essential for cytotoxicity. J Biol Chem. 1995;270:7876-81.

34. Chua JC, Douglass JA, Gillman A, O'Hehir RE, Meeusen EN. Galectin-10, a potential biomarker of eosinophilic airway inflammation. PLoS One. 2012;7:e42549.

35. Rothenberg ME, Hogan SP. The eosinophil. Annu Rev Immunol. 2006;24:147-74.

36. Gessner A, Mohrs K, Mohrs M. Mast cells, basophils, and eosinophils acquire constitutive IL-4 and IL-13 transcripts during lineage differentiation that are sufficient for rapid cytokine production. J Immunol. 2005;174:1063-72.

37. Wang Y-H, Angkasekwinai P, Lu N, Voo KS, Arima K, Hanabuchi $S$, et al. IL-25 augments type 2 immune responses by enhancing the expansion and functions of TSLP-DC-activated Th2 memory cells. J Exp Med. 2007;204:1837-47.

38. Shamri R, Xenakis JJ, Spencer LA. Eosinophils in innate immunity: an evolving story. Cell Tissue Res. 2011;343:57-83.

39. Long H, Liao W, Wang L, Lu Q. A Player and Coordinator: The Versatile Roles of Eosinophils in the Immune System. Transfus Med Hemother. 2016:43:96-108.

40. Halwani R, Al-Muhsen S, Al-Jahdali H, Hamid Q. Role of Transforming Growth Factor- $\beta$ in Airway Remodeling in Asthma. Am J Respir Cell Mol Biol. 2011;44:127-33.

41. Rosenberg HF, Dyer KD, Foster PS. Eosinophils: changing perspectives in health and disease. Nat Rev Immunol. 2013;13:9-22.

42. Shi H-Z. Eosinophils function as antigen-presenting cells. J Leukoc Biol. 2004;76:520-7.

43. Del Pozo V, De Andrés B, Martín E, Cárdaba B, Fernández JC, Gallardo S, et al. Eosinophil as antigen-presenting cell: activation of T cell clones and T cell hybridoma by eosinophils after antigen processing. Eur J Immunol. 1992;22:1919-25.
44. Johansson MW. Activation states of blood eosinophils in asthma. Clin Exp Allergy. 2014;44:482-98.

45. Nakajima H, Sano H, Nishimura T, Yoshida S, Iwamoto I. Role of vascular cell adhesion molecule 1/very late activation antigen 4 and intercellular adhesion molecule 1/lymphocyte function-associated antigen 1 interactions in antigen-induced eosinophil and T cell recruitment into the tissue. J Exp Med. 1994;179:1145-54.

46. Gonzalo JA, Lloyd CM, Kremer L, Finger E, Martinez-A C, Siegelman $\mathrm{MH}$, et al. Eosinophil recruitment to the lung in a murine model of allergic inflammation. The role of $\mathrm{T}$ cells, chemokines, and adhesion receptors. J Clin Invest. 1996:98:2332-45.

47. Bochner BS. Systemic activation of basophils and eosinophils: markers and consequences. J Allergy Clin Immunol. 2000;106:S292-302.

48. Johansson MW, Mosher DF. Activation of beta1 integrins on blood eosinophils by P-selectin. Am J Respir Cell Mol Biol. 2011;45:889-97.

49. Fulkerson PC, Rothenberg ME. Eosinophil Development, Disease Involvement, and Therapeutic Suppression. Adv Immunol. 2018:138:1-34.

50. O'Sullivan JA, Bochner BS. Eosinophils and eosinophilassociated diseases: An update. J Allergy Clin Immunol. 2018;141(2):505-17.

51. Abdala-Valencia $H$, Coden ME, Chiarella SE, Jacobsen EA, Bochner BS, Lee JJ, et al. Shaping eosinophil identity in the tissue contexts of development, homeostasis, and disease. J Leukoc Biol. 2018;104:95-108.

52. Chu VT, Fröhlich A, Steinhauser G, Scheel T, Roch T, Fillatreau S, et al. Eosinophils are required for the maintenance of plasma cells in the bone marrow. Nat Immunol. 2011;12:151-9.

53. MacKenzie JR, Mattes J, Dent LA, Foster PS. Eosinophils promote allergic disease of the lung by regulating CD4(+) Th2 lymphocyte function. J Immunol. 2001;167:3146-55.

54. Wang H-B, Ghiran I, Matthaei K, Weller PF. Airway eosinophils: allergic inflammation recruited professional antigenpresenting cells. J Immunol. 2007;179:7585-92.

55. Yang D, Rosenberg HF, Chen Q, Dyer KD, Kurosaka K, Oppenheim JJ. Eosinophil-derived neurotoxin (EDN), an antimicrobial protein with chemotactic activities for dendritic cells. Blood. 2003;102:3396-403.

56. Liu LY, Bates ME, Jarjour NN, Busse WW, Bertics PJ, Kelly EAB. Generation of Th1 and Th2 chemokines by human eosinophils: evidence for a critical role of TNF-alpha. J Immunol. 2007; 179:4840-8

57. Lotfi R, Lotze MT. Eosinophils induce DC maturation, regulating immunity. J Leukoc Biol. 2008;83:456-60.

58. Elishmereni M, Bachelet I, Nissim Ben-Efraim AH, Mankuta D, Levi-Schaffer F. Interacting mast cells and eosinophils acquire an enhanced activation state in vitro. Allergy. 2013:68:171-9.

59. Bandeira-Melo C, Weller PF. Eosinophils and cysteinyl leukotrienes. Prostaglandins Leukot Essent Fatty Acids. 69:135-43.

60. Kritas SK, Saggini A, Cerulli G, Caraffa A, Antinolfi P, Pantalone $A$, et al. Neuropeptide NGF mediates neuro-immune response and inflammation through mast cell activation. J Biol Regul Homeost Agents. 2004;28:177-81. 
61. Hartman M, Piliponsky AM, Temkin V, Levi-Schaffer F. Human peripheral blood eosinophils express stem cell factor. Blood. 2001;97:1086-91.

62. Zheutlin LM, Ackerman SJ, Gleich GJ, Thomas LL. Stimulation of basophil and rat mast cell histamine release by eosinophil granule-derived cationic proteins. J Immunol. 1984;133:2180-5.

63. Haskell MD, Moy JN, Gleich GJ, Thomas LL. Analysis of signaling events associated with activation of neutrophil superoxide anion production by eosinophil granule major basic protein. Blood. 1995;86:4627-37.

64. Wu D, Molofsky AB, Liang H-E, Ricardo-Gonzalez RR, Jouihan $H A$, Bando JK, et al. Eosinophils sustain adipose alternatively activated macrophages associated with glucose homeostasis. Science. 2011;332:243-7.

65. Rosenberg HF, Phipps S, Foster PS. Eosinophil trafficking in allergy and asthma. J Allergy Clin Immunol. 2007;19:130310.

66. Venge P. Eosinophil activity in bronchial asthma. Allergy Proc. 1994;15:139-41.

67. Spencer LA, Bonjour K, Melo RCN, Weller PF. Eosinophil secretion of granule-derived cytokines. Front Immunol. 2014:5:496.

68. McLaren DJ, Mackenzie CD, Ramalho-Pinto FJ. Ultrastructural observations on the in vitro interaction between rat eosinophils and some parasitic helminths (Schistosoma mansoni, Trichinella spiralis and Nippostrongylus brasiliensis). Clin Exp Immunol. 1977;30:105-18.

69. Inoue $Y$, Matsuwaki $Y$, Shin S-H, Ponikau JU, Kita H. Nonpathogenic, environmental fungi induce activation and degranulation of human eosinophils. J Immunol. 2005; 175:5439-47.

70. Melo RCN, Spencer LA, Perez SA, Neves JS, Bafford SP, Morgan ES, et al. Vesicle-mediated secretion of human eosinophil granule-derived major basic protein. Lab Invest. 2009;89:76981.

71. Melo RCN, Spencer LA, Perez SA, Ghiran I, Dvorak AM, Weller PF. Human eosinophils secrete preformed, granule-stored interleukin-4 through distinct vesicular compartments. Traffic. 2005;6:1047-57.

72. Spencer LA, Melo RCN, Perez SA, Bafford SP, Dvorak AM, Weller PF. Cytokine receptor-mediated trafficking of preformed IL-4 in eosinophils identifies an innate immune mechanism of cytokine secretion. Proc Natl Acad Sci U S A. 2006;103:33338.

73. Pazdrak K, Young TW, Straub C, Stafford S, Kurosky A. Priming of eosinophils by GM-CSF is mediated by protein kinase Cbetall-phosphorylated L-plastin. J Immunol. 2011;186:648596.

74. Bandeira-Melo C, Hall JC, Penrose JF, Weller PF. Cysteinyl leukotrienes induce IL-4 release from cord blood-derived human eosinophils. J Allergy Clin Immunol. 2002;109:975-9.

75. Mahmudi-Azer S, Downey GP, Mogbel R. Translocation of the tetraspanin CD63 in association with human eosinophil mediator release. Blood. 2002;99:4039-47.

76. Carmo LA, Bonjour K, Ueki S, Neves JS, Liu L, Spencer LA, et al. CD63 is tightly associated with intracellular, secretory events chaperoning piecemeal degranulation and compound exocytosis in human eosinophils. J Leukoc Biol. 2016;100:391401.
77. Dvorak HF, Dvorak AM. Basophilic leucocytes: structure, function and role in disease. Clin Haematol. 1975;4:651-83.

78. Cheng JF, Ott NL, Peterson EA, George TJ, Hukee MJ, Gleich GJ, et al. Dermal eosinophils in atopic dermatitis undergo cytolytic degeneration. J Allergy Clin Immunol. 1997;99:683-92.

79. Saffari H, Hoffman LH, Peterson KA, Fang JC, Leiferman KM, Pease $L F$, et al. Electron microscopy elucidates eosinophil degranulation patterns in patients with eosinophilic esophagitis. J Allergy Clin Immunol. 2014;133:1728-34.e1.

80. Malm-Erjefält M, Greiff L, Ankerst J, Andersson M, Wallengren J, Cardell L-O, et al. Circulating eosinophils in asthma, allergic rhinitis, and atopic dermatitis lack morphological signs of degranulation. Clin Exp Allergy [Internet]. 2005 [cited 2018 Apr 19]:35:1334-40.

81. Wright BL, Ochkur SI, Olson NS, Shim KP, Jacobsen EA, Rank $M A$, et al. Normalized serum eosinophil peroxidase levels are inversely correlated with esophageal eosinophilia in eosinophilic esophagitis. Dis Esophagus. 2018;31(2).

82. Mazzeo C, Cañas JA, Zafra MP, Rojas Marco A, FernándezNieto M, Sanz V, et al. Exosome secretion by eosinophils: A possible role in asthma pathogenesis. J Allergy Clin Immunol. 2015;135:1603-13.

83. Cañas JA, Sastre B, Mazzeo $C$, Fernández-Nieto $M$, RodrigoMuñoz JM, González-Guerra $A$, et al. Exosomes from eosinophils autoregulate and promote eosinophil functions. J Leukoc Biol. 2017;101:1191-1199.

84. Cañas JA, Sastre B, Rodrigo-Muñoz JM, Fernández-Nieto M, Barranco P, Quirce S, et al. Eosinophil-derived exosomes contribute to asthma remodelling by activating structural lung cells. Clin Exp Allergy. 2018 Feb 16.

85. Wardlaw AJ, Dunnette S, Gleich GJ, Collins JV, Kay AB. Eosinophils and Mast Cells in Bronchoalveolar Lavage in Subjects with Mild Asthma: Relationship to Bronchial Hyperreactivity. Am Rev Respir Dis. 1988;137:62-9.

86. Fahy JV. Type 2 inflammation in asthma--present in most, absent in many. Nat Rev Immunol. 2015;15:57-65.

87. Wardlaw AJ. Molecular basis for selective eosinophil trafficking in asthma: A multistep paradigm. J Allergy Clin Immunol. 1999;104:917-26.

88. Eng SS, DeFelice ML. The Role and Immunobiology of Eosinophils in the Respiratory System: a Comprehensive Review. Clin Rev Allergy Immunol. 2016;50:140-58.

89. Stone KD, Prussin C, Metcalfe DD. IgE, mast cells, basophils, and eosinophils. J Allergy Clin Immunol. 2010;125:S73-80.

90. Venge J, Lampinen $M$, Håkansson L, Rak S, Venge $P$. Identification of IL-5 and RANTES as the major eosinophil chemoattractants in the asthmatic lung. J Allergy Clin Immunol. 1996;97:1110-5.

91. Sjöberg LC, Nilsson AZ, Lei $Y$, Gregory JA, Adner M, Nilsson GP. Interleukin 33 exacerbates antigen driven airway hyperresponsiveness, inflammation and remodeling in a mouse model of asthma. Sci Rep. 2017;7:4219.

92. Watson B, Gauvreau GM. Thymic stromal lymphopoietin: a central regulator of allergic asthma. Expert Opin Ther Targets. 2014;18:771-85.

93. Yao X, Sun Y, Wang W, Sun Y. Interleukin (IL)-25: Pleiotropic roles in asthma. Respirology. 2016;21:638-47.

94. Chen R, Smith SG, Salter B, El-Gammal A, Oliveria JP, Obminski $C$, et al. Allergen-induced increases in sputum levels of group 
2 innate lymphoid cells in subjects with asthma. Am J Respir Crit Care Med. 2017;196:700-12.

95. Steinke JW, Borish L. Th2 cytokines and asthma. Interleukin-4: its role in the pathogenesis of asthma, and targeting it for asthma treatment with interleukin-4 receptor antagonists. Respir Res. 2001;2:66-70.

96. Weller PF, Rand TH, Goelz SE, Chi-Rosso G, Lobb RR. Human eosinophil adherence to vascular endothelium mediated by binding to vascular cell adhesion molecule 1 and endothelial leukocyte adhesion molecule 1. Proc Natl Acad Sci U S A. 1991;88:7430-3

97. Pope SM, Brandt EB, Mishra A, Hogan SP, Zimmermann N Rothenberg $\mathrm{ME}$, et al. IL-13 induces eosinophil recruitment into the lung by an IL-5- and eotaxin-dependent mechanism. J Allergy Clin Immunol. 2001;108:594-601.

98. Pease JE, Williams TJ. Eotaxin and asthma. Curr Opin Pharmacol. 2001;1:248-53.

99. Blanchard C, Wang N, Stringer KF, Mishra A, Fulkerson PC, Abonia JP, et al. Eotaxin-3 and a uniquely conserved geneexpression profile in eosinophilic esophagitis. J Clin Invest. 2006;116:536-47.

100. Höchstetter R, Dobos G, Kimmig D, Dulkys Y, Kapp A, Elsner J. The CC chemokine receptor 3 CCR3 is functionally expressed on eosinophils but not on neutrophils. Eur J Immunol. 2000;30:2759-64.

101. Asquith KL, Ramshaw HS, Hansbro PM, Beagley KW, Lopez AF, Foster PS. The IL-3/IL-5/GM-CSF common receptor plays a pivotal role in the regulation of Th2 immunity and allergic airway inflammation. J Immunol. 2008;180:1199-206.

102. Laitinen LA, Haahtela T, Vilkka V, Lee TH, Spur BW. Leukotriene E4and granulocytic infiltration into asthmatic airways. Lancet. 1993:341:989-90.

103. Wardlaw AJ, Mogbel R, Cromwell O, Kay AB. Plateletactivating factor. A potent chemotactic and chemokinetic factor for human eosinophils. J Clin Invest. 1986;78:17016.

104. Kato M1, Kita H, Tachibana A, Hayashi Y, Tsuchida Y, Kimura $H$. Dual signaling and effector pathways mediate human eosinophil activation by platelet-activating factor. Int Arch Allergy Immunol. 2004;134 Suppl 1:37-43.

105. Monneret G, Gravel S, Diamond M, Rokach J, Powell WS Narumiya S, et al. Prostaglandin D2 is a potent chemoattractant for human eosinophils that acts via a novel DP receptor. Blood. 2001;98:1942-8.

106. Fahy J V., Wong H, Liu J, Boushey HA. Comparison of samples collected by sputum induction and bronchoscopy from asthmatic and healthy subjects. Am J Respir Crit Care Med. 1995;152:53-8.

107. Casciano J, Krishnan JA, Small MB, Buck PO, Gopalan G, Li C, et al. Burden of asthma with elevated blood eosinophil levels. BMC Pulm Med. 2016;16.

108. Anwar AR, Moqbel R, Walsh GM, Kay AB, Wardlaw AJ. Adhesion to fibronectin prolongs eosinophil survival. J Exp Med. 1993;177:839-43.

109. Venge P, Dahl R, Fredens K, Peterson CG. Epithelial injury by human eosinophils. Am Rev Respir Dis. 1988;138:S54-7.

110. Gleich GJ, Flavahan NA, Fujisawa T, Vanhoutte PM. The eosinophil as a mediator of damage to respiratory epithelium: A model for bronchial hyperreactivity. J Allergy Clin Immunol. 1988;81:776-81.
111. Schwingshackl A, Duszyk $M$, Brown $N$, Mogbel R. Human eosinophils release matrix metalloproteinase- 9 on stimulation with TNF-alpha. J Allergy Clin Immunol. 1999;104:983-9.

112. Fattouh R, Jordana M. TGF-beta, eosinophils and IL-13 in allergic airway remodeling: a critical appraisal with therapeutic considerations. Inflamm Allergy Drug Targets. 2008;7:224-36.

113. Feder LS, Stelts D, Chapman RW, Manfra D, Crawley Y, Jones $\mathrm{H}$, et al. Role of nitric oxide on eosinophilic lung inflammation in allergic mice. Am J Respir Cell Mol Biol. 1997;17:436-42.

114. Roos AB, Mori M, Grönneberg R, Österlund C, Claesson HE, Wahlström J, et al. Elevated exhaled nitric oxide in allergenprovoked asthma is associated with airway epithelial iNOS. PLoS One. 2014;9:e90018.

115. MacPherson JC, Comhair SAA, Erzurum SC, Klein DF, Lipscomb MF, Kavuru MS, et al. Eosinophils Are a Major Source of Nitric Oxide-Derived Oxidants in Severe Asthma: Characterization of Pathways Available to Eosinophils for Generating Reactive Nitrogen Species. J Immunol. 2001;166:5763-72.

116. Sanders SP, Zweier JL, Harrison SJ, Trush MA, Rembish SJ, Liu MC. Spontaneous oxygen radical production at sites of antigen challenge in allergic subjects. Am J Respir Crit Care Med. 1995;151:1725-33.

117. Luna-Gomes T, Bozza PT, Bandeira-Melo C. Eosinophil recruitment and activation: the role of lipid mediators. Front Pharmacol. 2013;4:27.

118. Isobe $Y$, Arita $M$, Matsueda $S$, Iwamoto $R$, Fujihara $T$, Nakanishi $H$, et al. Identification and structure determination of novel anti-inflammatory mediator resolvin E3, 17,18-dihydroxyeicosapentaenoic acid. J Biol Chem. 2012;287:10525-34.

119. Rothenberg ME. Biology and treatment of eosinophilic esophagitis. Gastroenterology. 2009;137:1238-49.

120. Li W, Gao P, Zhi Y, Xu W, Wu Y, Yin J, et al. Periostin: its role in asthma and its potential as a diagnostic or therapeutic target. Respir Res. 2015;16:57.

121. Politi E, Angelakopoulou A, Grapsa Di, Zande M, Stefanaki $\mathrm{K}$, Panagiotou I, et al. Filaggrin and Periostin Expression Is Altered in Eosinophilic Esophagitis and Normalized with Treatment. J Pediatr Gastroenterol Nutr. 2017;65:47-52.

122. Blanchard C, Mingler MK, McBride M, Putnam PE, Collins MH, Chang $G$, et al. Periostin facilitates eosinophil tissue infiltration in allergic lung and esophageal responses. Mucosal Immunol. 2008;1:289-96.

123. Pearce N, Pekkanen J, Beasley R. How much asthma is really attributable to atopy? Thorax. 1999;54:268-72.

124. Masuoka M, Shiraishi H, Ohta S, Suzuki S, Arima K, Aoki S, et al. Periostin promotes chronic allergic inflammation in response to Th2 cytokines. J Clin Invest. 2012;122:2590-600.

125. Greenberger PA. Allergic bronchopulmonary aspergillosis. J Allergy Clin Immunol. 2002;110:685-92.

126. Choi JH, Kim MA, Park HS. An update on the pathogenesis of the upper airways in aspirin-exacerbated respiratory disease. Curr Opin Allergy Clin Immunol. 2014;14(1):1-6

127. Lummus ZL, Wisnewski AV, Bernstein DI. Pathogenesis and disease mechanisms of occupational asthma. Immunol Allergy Clin North Am. 2011;31:699-716.

128. Cottin V, Cordier JF, Allen J, Ogawa H, Nakamura H, Takayanagi N, et al. Eosinophilic Lung Diseases. Crit Care. 2006;69:605-8.

129. Cottin V, Cordier JF. Eosinophilic pneumonias. Allergy. 2005:60(7):841-57. 
130. Kroegel C, Foerster M, Grahmann PR, Braun R. Eosinophil priming and migration in idiopathic pulmonary fibrosis. European Respiratory Journal. 1998;11:999-1001.

131. Davis BP, Rothenberg ME. Eosinophils and cancer. Cancer Immunol Res. 2014;2:1-8.

132. Klion A. Hypereosinophilic syndrome: current approach to diagnosis and treatment. Annu Rev Med. 2009;60:293-306.

133. Barnes PJ, Adcock IM. How do corticoids work in asthma? Ann Intern Med. 2003;139:359-70.

134. Cardet JC, Israel E. Update on reslizumab for eosinophilic asthma. Expert Opin Biol Ther. 2015;15:1531-9.

135. Hilvering B, Xue L, Pavord ID. Evidence for the efficacy and safety of anti-interleukin-5 treatment in the management of refractory eosinophilic asthma. Ther Adv Respir Dis. 2015;9:135-45.

136. Robinson DS, Kariyawasam HH. Mepolizumab for eosinophilic severe asthma: recent studies. Expert Opin Biol Ther. 2015;15:909-14.

137. National Institute for Health and Care and Excellence. Mepolizumab for treating severe refractory eosinophilic asthma. 2017. https://www.nice.org.uk/guidance/ta431 accessed 21/11/2017

138. Haldar P, Brightling CE, Hargadon B, Gupta S, Monteiro W, Sousa $A$, et al. Mepolizumab and exacerbations of refractory eosinophilic asthma. N Engl J Med. 2009;360:973-84.

139. Pavord ID, Korn S, Howarth P, Bleecker ER, Buhl R, Keene ON, et al. Mepolizumab for severe eosinophilic asthma (DREAM): a multicentre, double-blind, placebo-controlled trial. Lancet. 2012;380:651-9.

140. Ortega HG, Liu MC, Pavord ID, Brusselle GG, FitzGerald JM, Chetta A, et al.; MENSA Investigators. Mepolizumab treatment in patients with severe eosinophilic asthma. $\mathrm{N}$ Engl J Med. 2014;371:1198-207.

141. National Institute for Health and Care and Excellence. Reslizumab for treating severe eosinophilic asthma. 2017. avalaible from https://www.nice.org.uk/guidance/ta479 accessed 21/11/2017

142. Castro M, Zangrilli J, Wechsler ME, Bateman ED, Brusselle GG, Bardin P, Murphy K, Maspero JF, O'Brien C, Korn S. Reslizumab for inadequately controlled asthma with elevated blood eosinophil counts: results from two multicentre, parallel, double-blind, randomised, placebo-controlled, phase 3 trials. Lancet Respir Med. 2015;3:355-66.

143. Kolbeck R, Kozhich A, Koike M, Peng L, Andersson CK, Damschroder MM, et al. MEDI-563, a humanized anti-IL-5 receptor alpha mAb with enhanced antibody-dependent cell-mediated cytotoxicity function. J Allergy Clin Immunol. 2010;125:1344-53.e2.

144. Castro M, Wenzel SE, Bleecker ER, Pizzichini E, Kuna P, Busse $W W$, et al. Benralizumab, an anti-interleukin 5 receptor a monoclonal antibody, versus placebo for uncontrolled eosinophilic asthma: a phase $2 \mathrm{~b}$ randomised dose-ranging study. Lancet Respir Med. 2014;2:879-90.

145. FitzGerald JM, Bleecker ER, Nair P, Korn S, Ohta K, Lommatzsch $M$, et al. Benralizumab, an anti-interleukin-5 receptor $\alpha$ monoclonal antibody, as add-on treatment for patients with severe, uncontrolled, eosinophilic asthma (CALIMA): a randomised, double-blind, placebo-controlled phase 3 trial. Lancet. 2016;388:2128-41.
146. Bleecker ER, FitzGerald JM, Chanez P, Papi A, Weinstein SF, Barker $\mathrm{P}$, et al. Efficacy and safety of benralizumab for patients with severe asthma uncontrolled with high-dosage inhaled corticosteroids and long-acting $\beta 2$-agonists (SIROCCO): a randomised, multicentre, placebo-controlled phase 3 trial. Lancet. 2016;388:2115-27.

147. Wegmann M, Göggel R, Sel S, Sel S, Erb KJ, Kalkbrenner F, et al. Effects of a low-molecular-weight CCR-3 antagonist on chronic experimental asthma. Am J Respir Cell Mol Biol. 2007;36:61-7.

148. Komai M, Tanaka H, Nagao K, Ishizaki M, Kajiwara D, Miura T, et al. A novel CC-chemokine receptor 3 antagonist, Ki19003, inhibits airway eosinophilia and subepithelial/peribronchial fibrosis induced by repeated antigen challenge in mice. J Pharmacol Sci. 2010;112:203-13.

149. Ding C, Li J, Zhang X. Bertilimumab Cambridge Antibody Technology Group. Curr Opin Investig Drugs. 2004;5:1213-8.

150. Henderson WR Jr, Chi EY, Albert RK, Chu SJ, Lamm WJ, Rochon $Y$, et al. Blockade of CD49d (alpha4 integrin) on intrapulmonary but not circulating leukocytes inhibits airway inflammation and hyperresponsiveness in a mouse model of asthma. J Clin Invest. 1997; 100:3083-92.

151. Okigami $H$, Takeshita K, Tajimi M, Komura $H$, Albers $M$, Lehmann $T E$, et al. Inhibition of eosinophilia in vivo by a small molecule inhibitor of very late antigen (VLA)-4. Eur J Pharmacol. 2007;559:202-9.

152. Abbas M, Lalive PH, Chofflon M, Simon HU, Chizzolini C, Ribi C. Hypereosinophilia in patients with multiple sclerosis treated with natalizumab. Neurology. 2011;77:1561-4.

153. Barnes N, Pavord I, Chuchalin A, Bell J, Hunter M, Lewis T, et al. A randomized, double-blind, placebo-controlled study of the CRTH2 antagonist OC000459 in moderate persistent asthma. Clin Exp Allergy. 2012;42:38-48.

154. Géhin M, Strasser DS, Zisowsky J, Farine $H$, Groenen PM, Dingemanse J, et al. A novel CRTH2 antagonist: Singleand multiple-dose tolerability, pharmacokinetics, and pharmacodynamics of ACT-453859 in healthy subjects. J Clin Pharmacol. 2015;55:787-97.

155. Shin N, Covington M, Bian D, Zhuo J, Bowman K, Li Y, et al. INCB38579, a novel and potent histamine $\mathrm{H}_{4}$ receptor small molecule antagonist with anti-inflammatory pain and antipruritic functions. Eur J Pharmacol. 2012;675:47-56.

156. Salcedo C, Pontes C, Merlos M. Is the H4 receptor a new drug target for allergies and asthma? Front Biosci (Elite Ed). 2013;5:178-87.

157. Borish LC, Nelson HS, Corren J, Bensch G, Busse WW, Whitmore $\mathrm{JB}$, et al. Efficacy of soluble IL-4 receptor for the treatment of adults with asthma. J Allergy Clin Immunol. 2001;107:963-70.

158. Gauvreau GM, Boulet LP, Cockcroft DW, Fitzgerald JM, Carlsten C, Davis BE, et al. Effects of interleukin-13 blockade on allergen-induced airway responses in mild atopic asthma. Am J Respir Crit Care Med. 2011;183:1007-14.

159. Corren J, Lemanske RF, Hanania NA, Korenblat PE, Parsey MV, Arron JR, et al. Lebrikizumab treatment in adults with asthma. N Engl J Med. 2011;365:1088-98.

160. Corren J, Busse W, Meltzer EO, Mansfield L, Bensch G, Fahrenholz J, et al. A randomized, controlled, phase 2 study of AMG 317, an IL-4Ralpha antagonist, in patients with asthma. Am J Respir Crit Care Med. 2010;181:788-96. 
161. Wenzel S, Wilbraham D, Fuller R, Getz EB, Longphre M. Effect of an interleukin-4 variant on late phase asthmatic response to allergen challenge in asthmatic patients: results of two phase 2a studies. Lancet. 2007;370:1422-31.

162. Wenzel S, Ford L, Pearlman D, Spector S, Sher L, Skobieranda F, et al. Dupilumab in persistent asthma with elevated eosinophil levels. N Engl J Med. 2013;368:2455-66.

163. Wenzel S, Castro M, Corren J, Maspero J, Wang L, Zhang B, et al. Dupilumab efficacy and safety in adults with uncontrolled persistent asthma despite use of medium-to-high-dose inhaled corticosteroids plus a long-acting $\beta 2$ agonist: a randomised double-blind placebo-controlled pivotal phase $2 \mathrm{~b}$ dose-ranging trial. Lancet. 2016;388:31-44.

164. Beck LA, Thaçi D, Hamilton JD, Graham NM, Bieber T, Rocklin $\mathrm{R}$, et al. Dupilumab treatment in adults with moderate-tosevere atopic dermatitis. N Engl J Med. 2014;371:130-9.

165. Wenzel S, Wilbraham D, Fuller R, Getz EB, Longphre M. Effect of an interleukin-4 variant on late phase asthmatic response to allergen challenge in asthmatic patients: results of two phase 2a studies. Lancet. 2007;370:1422-31.

166. Patterson MF, Borish L, Kennedy JL. The past, present, and future of monoclonal antibodies to IL-5 and eosinophilic asthma: a review. J Asthma Allergy. 2015;8:125-34.

167. Catley MC, Coote J, Bari M, Tomlinson KL. Monoclonal antibodies for the treatment of asthma. Pharmacol Ther. 2011;132:333-51.

168. Molfino NA1, Gossage D, Kolbeck R, Parker JM, Geba GP. Molecular and clinical rationale for therapeutic targeting of interleukin-5 and its receptor. Clin Exp Allergy. 2012;42:712-37.

169. Kolbeck R, Kozhich A, Koike M, Peng L, Andersson CK, Damschroder MM, et al. MEDI-563, a humanized anti-IL-5 receptor alpha mAb with enhanced antibody-dependent cell-mediated cytotoxicity function. J Allergy Clin Immunol. 2010;125:1344-53.e2.

170. Song DJ, Cho JY, Miller M, Strangman W, Zhang M, Varki A, et al. Anti-Siglec-F antibody inhibits oral egg allergen induced intestinal eosinophilic inflammation in a mouse model. Clin Immunol. 2009;131:157-69.

171. Kiwamoto T, Kawasaki N, Paulson JC, Bochner BS. Siglec-8 as a drugable target to treat eosinophil and mast cell-associated conditions. Pharmacol Ther. 2012;135:327-36.
172. Busse W, Corren J, Lanier BQ, McAlary M, Fowler-Taylor A, Cioppa GD, et al. Omalizumab, anti-lgE recombinant humanized monoclonal antibody, for the treatment of severe allergic asthma. J Allergy Clin Immunol. 2001;108:184-90.

173. Solèr M, Matz J, Townley R, Buhl R, O'Brien J, Fox $H$, et al. The anti-lgE antibody omalizumab reduces exacerbations and steroid requirement in allergic asthmatics. Eur Respir J. 2001;18:254-61.

174. Holgate ST1, Djukanović R, Casale T, Bousquet J. Antiimmunoglobulin $\mathrm{E}$ treatment with omalizumab in allergic diseases: an update on anti-inflammatory activity and clinical efficacy. Clin Exp Allergy. 2005;35:408-16.

175. Legrand F, Tomasevic N, Simakova O, Lee CC, Wang $Z$, Raffeld $M$, et al. The eosinophil surface receptor epidermal growth factor-like module containing mucinlike hormone receptor 1 (EMR1): a novel therapeutic target for eosinophilic disorders. J Allergy Clin Immunol. 2014;133:1439-47, 1447.e1-8.

176. Gauvreau GM, O'Byrne PM, Boulet LP, Wang Y, Cockcroft D, Bigler J, et al. Effects of an anti-TSLP antibody on allergeninduced asthmatic responses. N Engl J Med. 2014;370:210210.

177. Siemers ER, Quinn JF, Kaye J, Farlow MR, Porsteinsson $A$, Tariot $P$, et al. Effects of a gamma-secretase inhibitor in a randomized study of patients with Alzheimer disease. Neurology. 2006;66:602-4.

178. Gotlib J. World Health Organization-defined eosinophilic disorders: 2017 update on diagnosis, risk stratification, and management. Am J Hematol. 2017;92:1243-59.

\section{Victoria del Pozo}

Immunology Department

IIS-Fundación Jiménez Díaz

Av. Reyes Católicos, 2

28040 Madrid, Spain

E-mail:vpozo@fjd.es 